\title{
Vegetation of the rock habitats of the Sekhukhuneland Centre of Plant Endemism, South Africa
}

\author{
S.J. SIEBERT**, A.E. VAN WYK*, G.J. BREDENKAMP* and F. SIEBERT*
}

Keywords: biodiversity, Braun-Blanquet, conservation, endemism, phytosociology, Sekhukhuneland, syntaxonomy, ultramafic rock habitats

ABSTRACT

\begin{abstract}
A hierarchical classification, description, and ecological and floristic interpretations are presented on the vegetation types of the ultramafic rock habitats of the Sekhukhuneland Centre of Plant Endemism. Relevés were compiled in 100 stratified random plots. A TWINSPAN classification, refined by Braun-Blanquet procedures, revealed 17 plant communities, which are classified into 13 associations belonging to four proposed alliances. Many new syntaxa are ecologically interpreted and described. For each syntaxon, the species richness, endemism and conservation status was determined. Much of the plant community distribution can be ascribed to specific habitat preference. The floristic and habitat information, proposed classification, general description and vegetation key are provided to aid future identification of conservation areas, land use planning and research. An ordination (DECORANA) based on floristic data confirmed potential relationships that could exist between the plant communities and associated habitats and environmental gradients.
\end{abstract}

\section{INTRODUCTION}

Although several phytosociological studies have been conducted on vegetation types of the northeastern Drakensberg Escarpment and adjacent areas of Limpopo [Northern Province] and Mpumalanga (Deall 1985; Bloem 1988; Matthews 1991; Burgoyne 1995), the vegetation of the Sekhukhuneland Centre of Plant Endemism (SCPE) (Van Wyk \& Smith 2001; Siebert \& Van Wyk 2001) has never been studied in detail. Recently much work has been done to document the plant diversity and vegetation of this poorly known micro-regional Centre of Plant Endemism (Siebert et al. 2002a-e; Siebert et al. 2003). The vegetation of rock habitats is the last major vegetation type of Sekhukhuneland to be described. Its extent of occurrence is $\pm 4000 \mathrm{~km}^{2}$ and is characterized by considerable diversity in geology (Kent 1980) and physiography (Land Type Survey Staff 1987). In South Africa rock outcrop communities have received very little attention from botanists and environmentalists in the past (Bredenkamp \& Deutschlander 1995), probably due to their low agricultural potential. However, ultramafic rock habitats are floristically noteworthy and have high conservation significance, because many endemics with distributions correlated with this geological substrate occur here (Madulid \& Agoo 1995; Meirelles et al. 1999; Reddy et al. 2001; Siebert et al. 2001).

Various vegetation types have been identified for the rock habitats of the northeastern Drakensberg Escarpment (Matthews et al. 1991; Matthews et al. 1992) and western Rustenburg Layered Suite (Coetzee 1975; Van der Meulen 1979), areas that have a strong floristic relationship with the SCPE (Siebert 1998). The areas where the rocky outcrops of the SCPE occur were mapped as

\footnotetext{
* Department of Botany. University of Pretoria, 0002 Pretoria.

Present address: Department of Botany. University of Zululand, 3886 Kwadlangezwa.

MS. received: 2002-02-27.
}

three major Veld Types by Acocks (1988), namely Mixed Bushveld (18), Sourish Mixed Bushveld (19) and North-Eastern Sandy Highveld (57). A more generalized classification of the same region's vegetation is given by Low \& Rebelo (1996), who recognize one broad Vegetation Type for the study area, namely Mixed Bushveld (18).

The vegetation of the SCPE can be broadly described as mountain bushveld that forms a mosaic with moist grassland in the south and semi-arid bushveld in the north. In this region of undulating hills and mountains, a predominant and characteristic feature is the scattered rock habitats. The vegetation of rock habitats described here only includes those plant communities identified as the Hippobromus pauciflorus-Rhoicissus tridentata Rock Outcrop Vegetation by Siebert et al. (2002a). This vegetation forms a mosaic distribution with the other major vegetation types of the SCPE. Forty-one of the Sekhukhuneland endemics/near-endemics and threatened taxa are known to occur in rock habitats (Siebert 1998).

The present paper forms part of a comprehensive vegetation and floristic survey of the SCPE (Siebert 2001). It is envisaged that the identification, classification and description of the various vegetation units will contribute to the knowledge of the plant diversity and biological intricacies of the region. This paper provides ecological and floristic data of the region's rocky habitat communities on ultramafic outcrops and associated habitats, by characterizing and interpreting the vegetation units. Classification of the vegetation is basic to the formulation of management policies to co-ordinate and implement proper land use in bioregional planning activities. An assessment of the plant diversity, endemism and Red Data List taxa of the plant communities of the study area is supplied to aid future conservation actions and ecosystem management strategies. Such information is needed to build an adequate database of natural features and other land uses related to sustainable development (Bedward et al. 1992). 


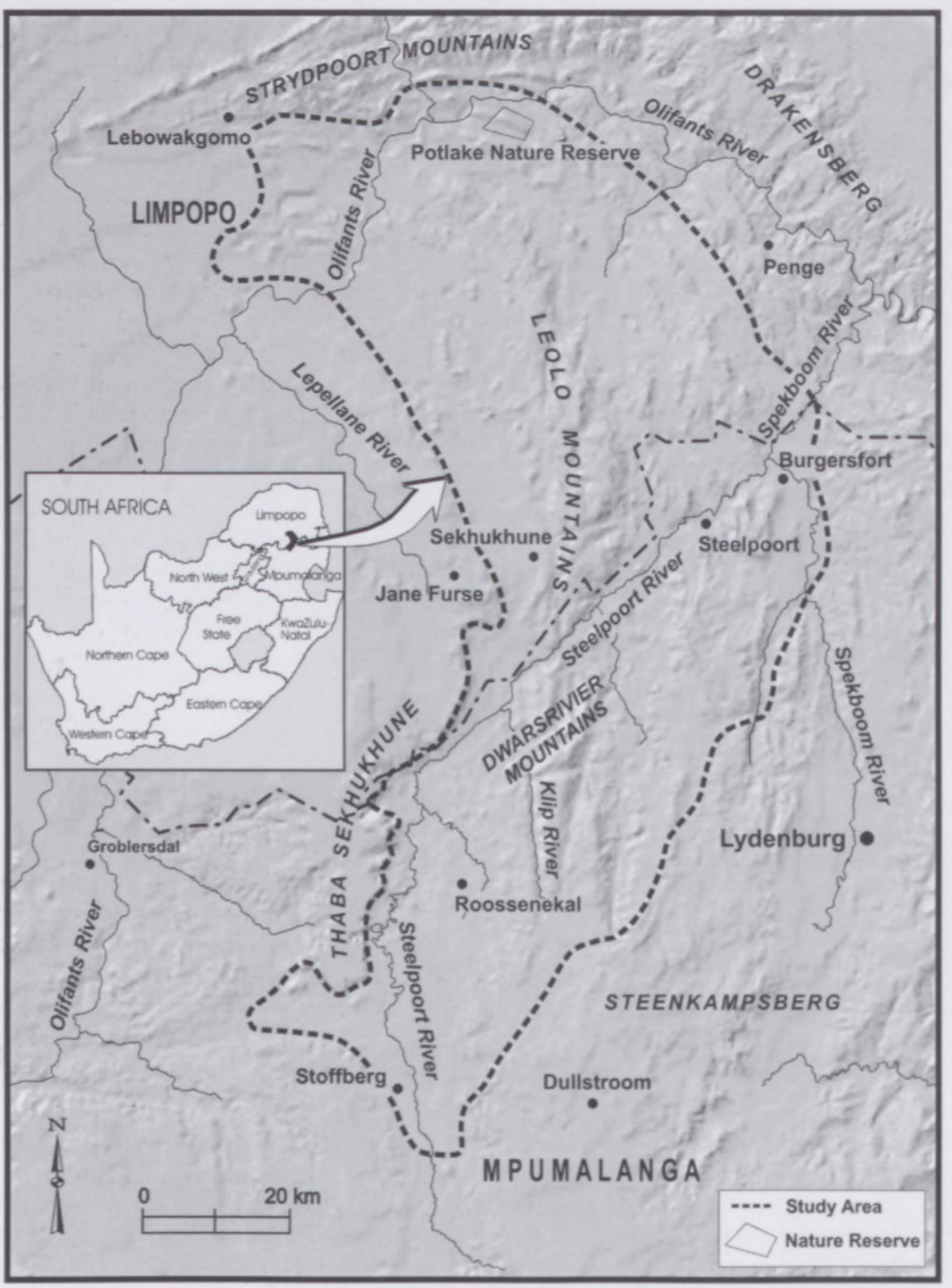

FIGURE 1.-Extent of occurrence of rock habitats of Sekhukhuneland Centre of Plant Endemism in Limpopo [Northern Province] and Mpumalanga, South Africa.

\section{STUDY AREA}

The study area is located in the SCPE and is defined in Siebert et al. (2002a) as an area more or less restricted to the Rustenburg Layered Suite, one of the stratigraphic units of the Bushveld Complex (Figure 1). The Rustenburg Layered Suite is known for its concentric belts of norite and pyroxenite (Visser et al. 1989). In addition, large quantities of heavy metals such as iron, chromium and platinum are present in the different zones of the suite (Schurmann et al. 1998; Viljoen \& Schurmann 1998).

The study area lies in the summer rainfall region and the mean annual rainfall is $578 \mathrm{~mm}$ (South African Weather Bureau 1998), of which nearly half $(48 \%)$ is received between December and February (summer); a mean of $283 \mathrm{~mm}$ for these three months (Erasmus 1985). However, the rainfall pattern is strongly influenced by the local topography and varies from as little as $400 \mathrm{~mm}$ in the Steelpoort and Olifants River valleys in the north, to an estimated $700 \mathrm{~mm}$ on the Leolo Mountains and the Dwarsrivier Mountains in the south
(Siebert 1998). Perhaps the most outstanding climatic feature of the drier central and northern parts of the SCPE is that it lies in the rainshadow of the northeastern Drakensberg Escarpment.

Annual temperatures of the study area range from $-4.5^{\circ} \mathrm{C}$ to $38^{\circ} \mathrm{C}$, with a daily mean of $18.5^{\circ} \mathrm{C}$ (South African Weather Bureau 1998). The northern and western parts of the study area are on average warmer than the southern and eastern parts (Siebert 1998). The northern parts of the region exhibit mean daily temperatures of $28.3^{\circ} \mathrm{C}$ maximum and $7.2^{\circ} \mathrm{C}$ minimum. Temperatures vary at different localities within the area, also correlating strongly with physiographic features, being higher in the low-lying valleys and lower on the high-lying plateau (Buckle 1996).

\section{METHODS}

A first approximation of a vegetation classification, based on the total floristic data set of 415 stratified random sample plots (Siebert et al. 2002a) was obtained by the application of Two-Way Indicator Species Analysis 
(TWINSPAN) (Hill 1979a). This first step of an objective multivariate classification identified six major vegetation types for the Sekhukhuneland Centre (Siebert et al. 2002a). These results were used to subdivide the data set into phytosociological tables. One of these tables represented floristic and habitat data of rock habitats (100 relevés) and was again subjected to TWINSPAN. The resultant classification was further refined by BraunBlanquet procedures in the MEGATAB computer programme (Hennekens 1996b).

For sampling purposes, stratification was based on terrain type, aspect and vegetation structure. To standardize the plot size and to counter the bias of different scale (Jonsson \& Moen 1998), plot size was fixed at $400 \mathrm{~m}^{2}$. Within each sample plot, all species were recorded and a cover-abundance value was assigned to each species according to the Braun-Blanquet scale (Mueller-Dombois \& Ellenberg 1974). Plant species names conform to those of Retief \& Herman (1997), and practice followed in the H.G.W.J. Schweickerdt Herbarium (PRU), University of Pretoria. Terminology to describe vegetation structure follows Edwards (1983). Environmental data recorded for each sample plot include terrain type (Land Type Survey Staff 1987, 1988, 1989), aspect, slope, geology (Visser et al. 1989), soil type (MacVicar et al. 1991) and rockiness of soil surface. Longitude and latitude readings were also recorded for each sample plot using a Global Positioning System (GPS). All relevé data are stored in the TURBOVEG database (Hennekens 1996a), managed by the Department of Botany, University of Pretoria (Mucina et al. 2000). Syntaxa are named in accordance with the Code of Phytosociological Nomenclature (Weber et al. 2000).
The ordination algorithm Detrended Correspondence Analysis (DECORANA) (Hill 1979b) (Figure 2) was applied to highlight potential gradients in the vegetation, and the relationship between these plant communities and the physical environment.

To facilitate the identification of areas of high conservation potential, the alpha diversities of the different plant communities were calculated. The alpha diversity (plant species richness) is defined as the number of species per unit area within a homogeneous community or the total number of species per community (Whittaker 1977). A $400 \mathrm{~m}^{2}$ sample plot was taken as the unit area.

The geographical distribution of all the taxa was verified at the National Herbarium (PRE), Pretoria, to identify any taxa endemic/near-endemic to the region (Siebert 1998). All taxa were also checked against the Red Data List of southern African plants (Hilton-Taylor 1996) to determine their conservation status.

\section{RESULTS}

\section{Classification of vegetation}

The floristic data analysis resulted in the identification of 17 plant communities of the Hippobromus pauciflorus-Rhoicissus tridentata Rock Outcrop Vegetation (Table 1). These were subsequently hierarchically classified into 13 associations. Four major syntaxa are recognized on the grounds of the physical environment and are proposed as potential alliances, with all 13 associations and eight subassociations classified under them. No macro-climatic or geological variation plays a role in

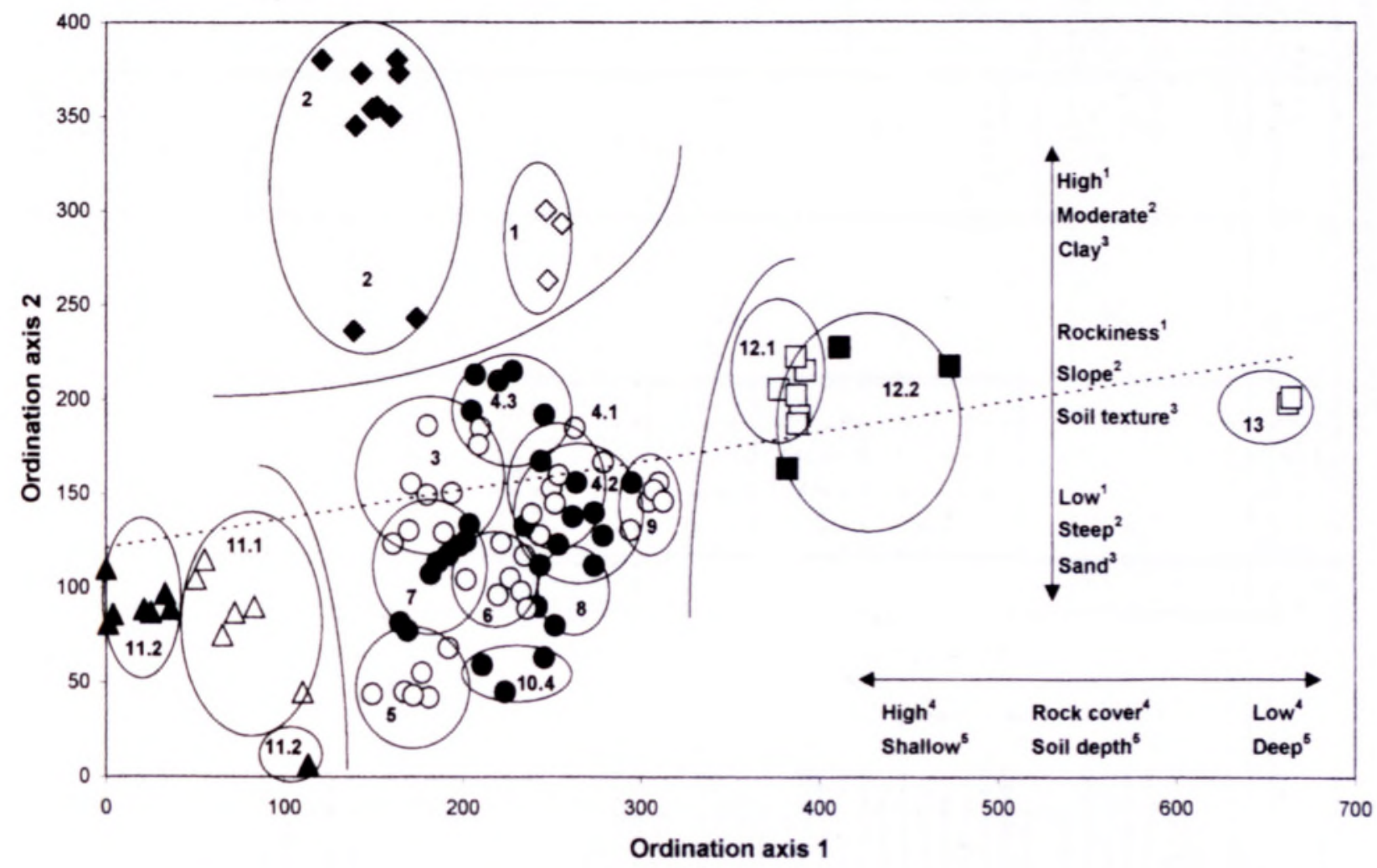

FIGURE 2.-Relative positions of all relevés along first and second axis of ordination of rock habitat vegetation in Sekhukhuneland Centre of Plant Endemism. Numbers refer to plant communities in Table 1. 


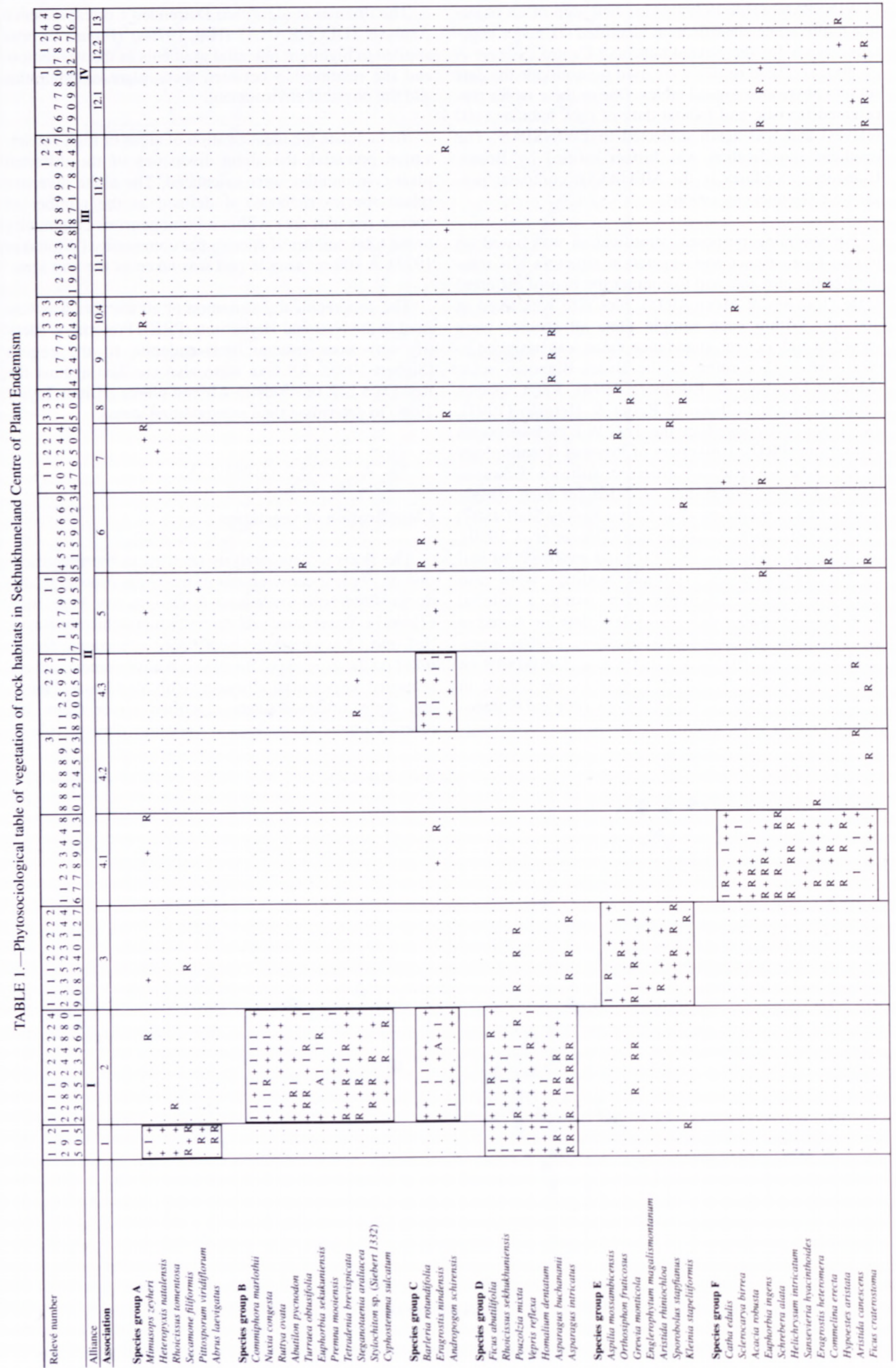




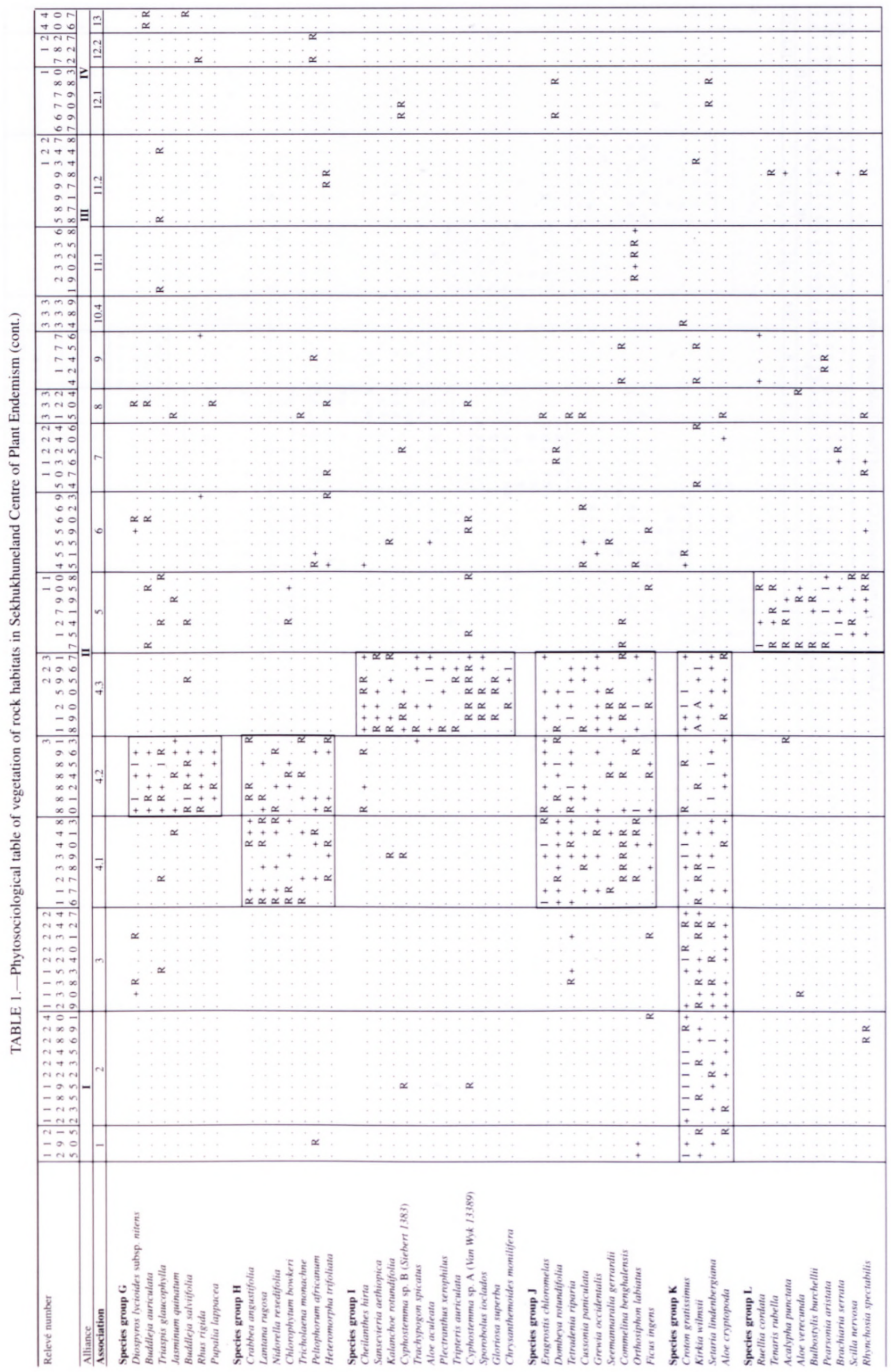




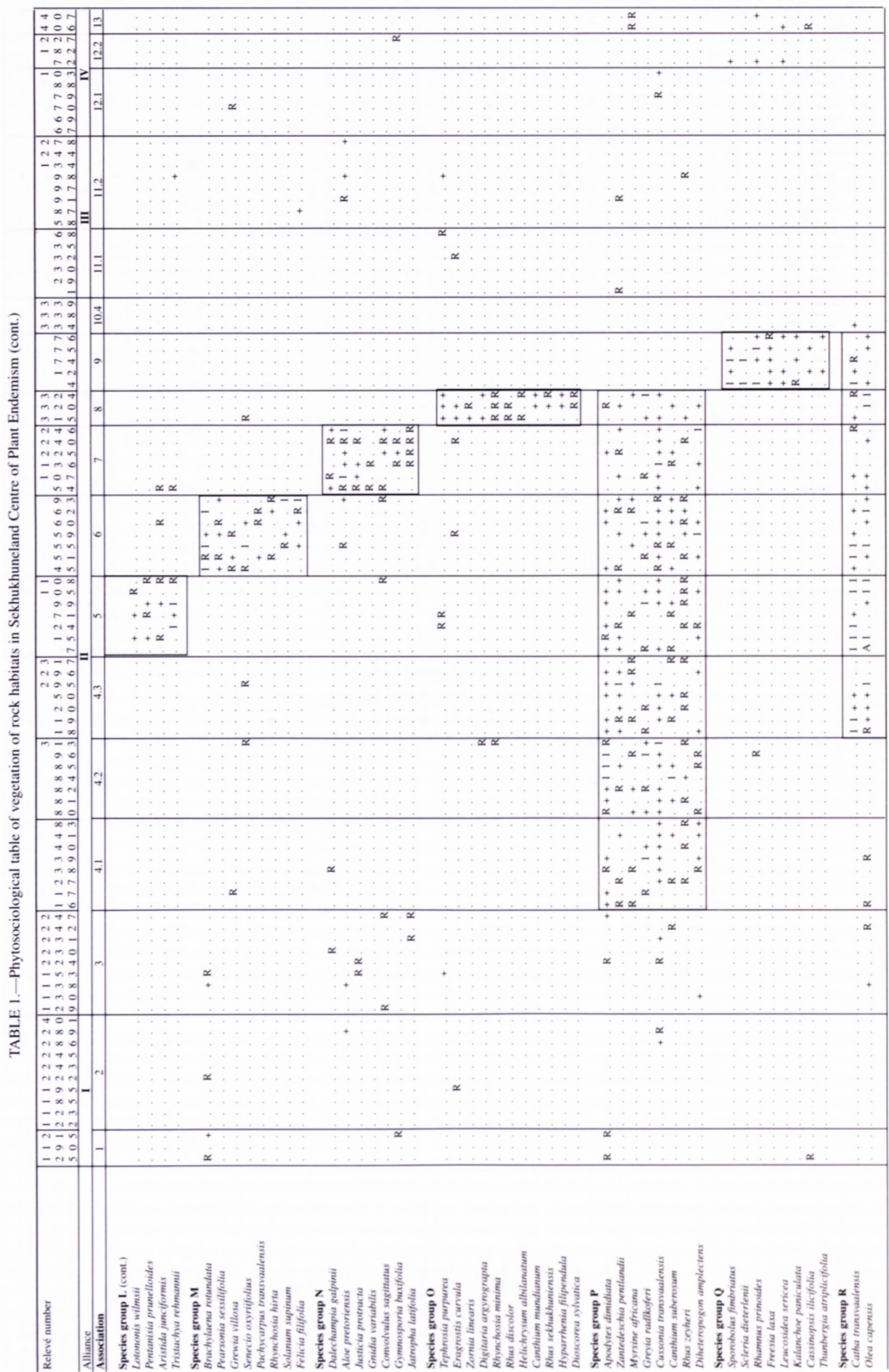




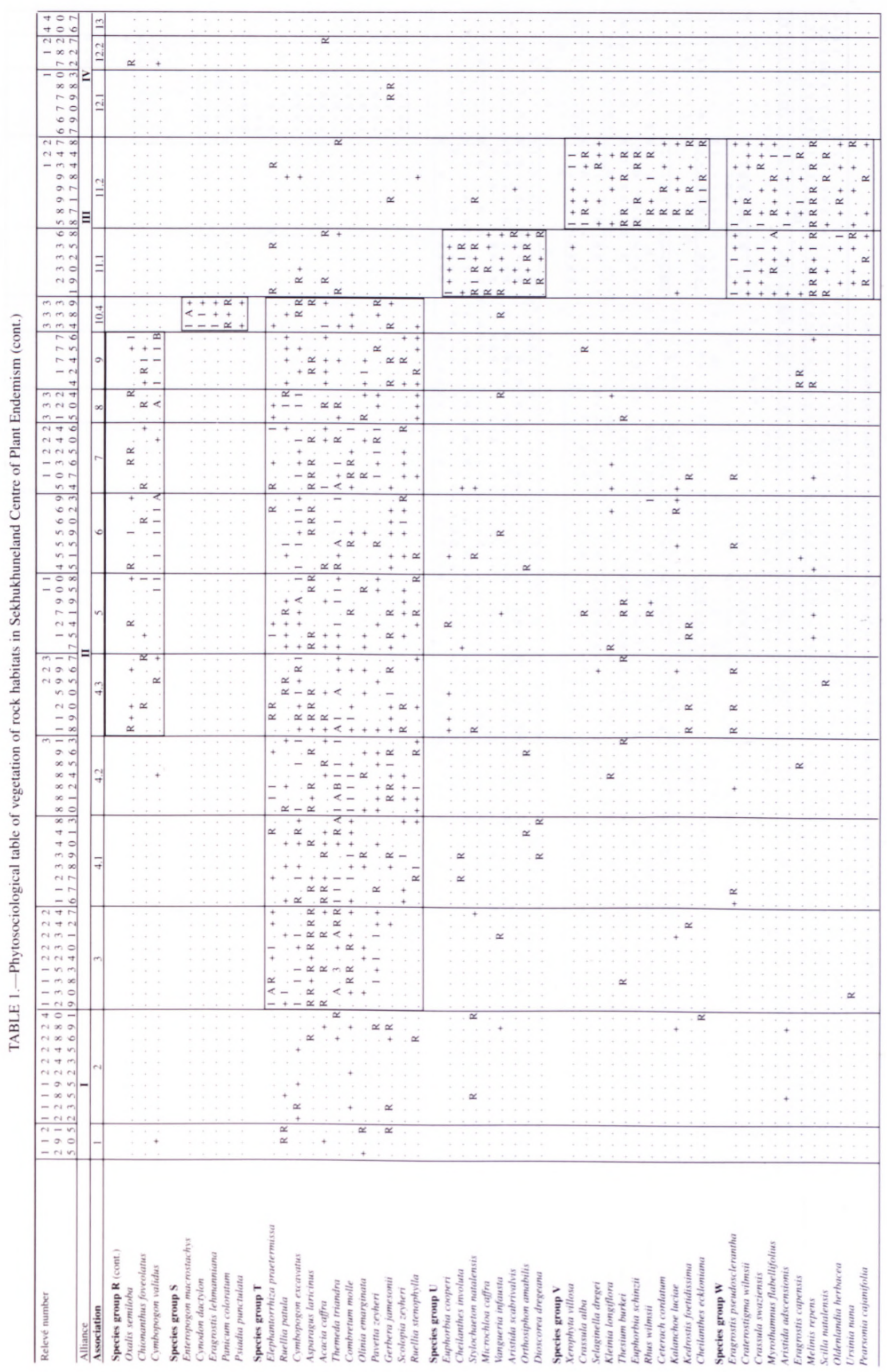




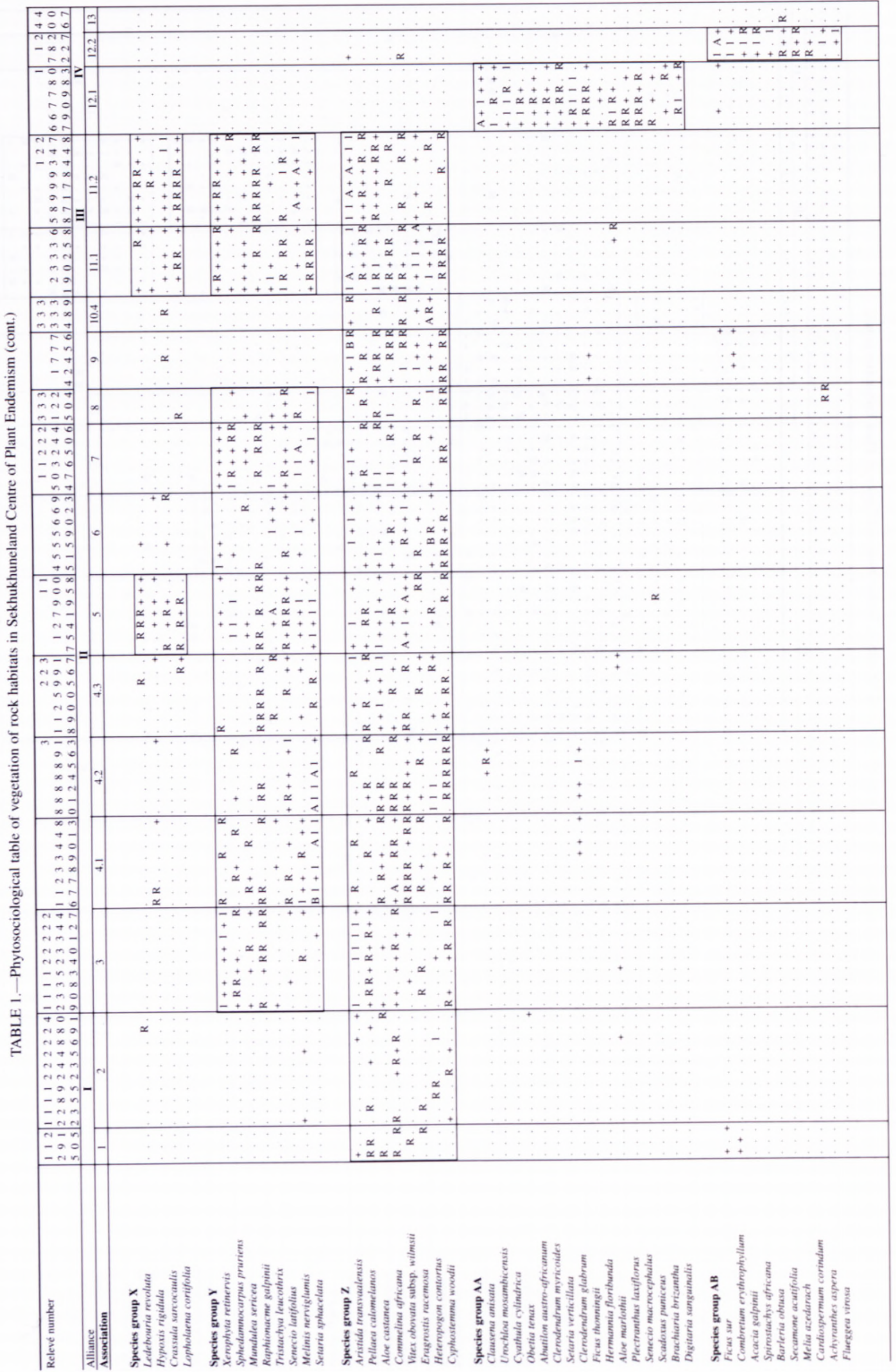




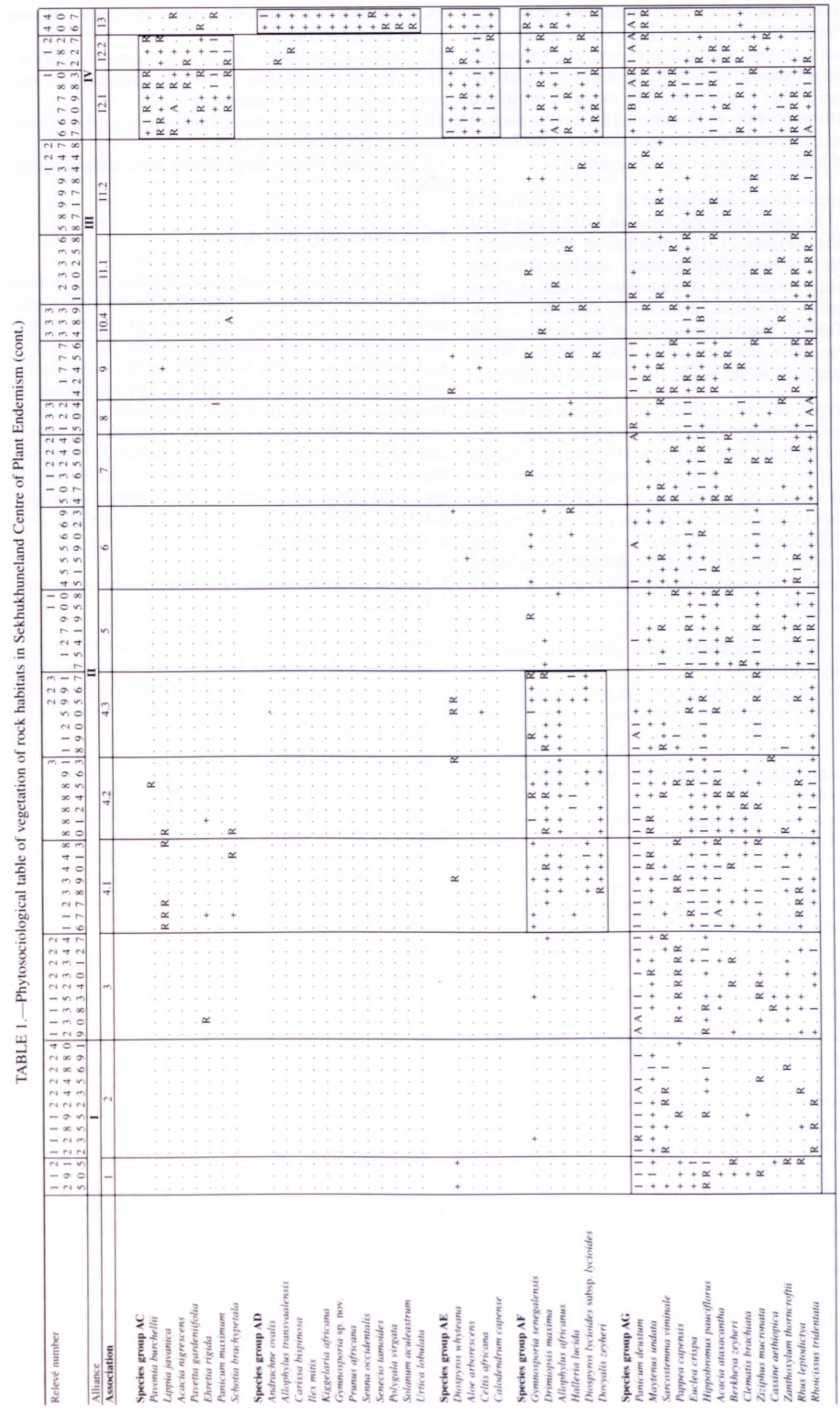


local differentiation of the plant communities. Plant communities relate to soil type, rockiness and terrain type, with aspect and slope also of importance. The four major communities (potential alliances) are distinctive and easily distinguishable in the field. This might be attributed to the uniformity of the environmental factors for each of the major communities, causing a distinct distribution pattern of habitats and associated vegetation.

The hierarchical classification of the vegetation is reinforced by the correlation between habitat and plant communities (Figure 2). The distribution of Sekhukhuneland Centre endemic/near-endemic and Red Data List taxa among various plant communities is listed in Table 2. A summary of selected community attributes is supplied in Table 3. Plant communities of the Hippobromus pauciflorus-Rhoicissus tridentata Rock Outcrop Vegetation recognized in the SCPE are classified as follows:

Four types of rock habitats are recognized for the region, namely rocky outcrops (I), rocky ridges (II), rocky flats (III) and rocky refugia (IV). Rocky outcrops are defined as a mass of exposed stacked boulders on hills. Rocky ridges are defined as exposed reefs and scattered groups of rocks and boulders on the sides of mountains/hills. Rocky flats are defined as rock beds exposed at ground level. Rocky refugia are defined as sheltered rocky areas of scattered boulders around caves, in kloofs and below cliffs.

\section{Setario lindenbergianae-Crotion gratissimi Alliance of Rocky Outcrops}

1. Vepro reflexae-Mimusopetum zeyheri Association

2. Setario lindenbergianae-Crotonetum gratissimi Association

\section{Themedo triandrae-Combretion mollis Alliance of Rocky Ridges}

3. Grewio monticolae-Elephantorrhizetum praetermissae Association

4. Setario lindenbergianae-Combretetum mollis Association

4.1. Setario lindenbergianae-Combretetum mollis cathetosum edulis Subassociation

4.2. Setario lindenbergianae-Combretetum mollis diospyretosum nitensis Subassociation

4.3. Setario lindenbergianae-Combretetum mollis aloetum aculeatae Subassociation

5. Brachiario serratae-Viticetum wilmsii Association

6. Cymbopogono validi-Brachylaenetum rotundatae Association

7. Aloo pretoriensis-Xerophytetum retinervis Association

8. Tephrosio purpureae-Rhoicissetum tridentatae Association

9. Sporobolo fimbriati-Rhamnetum prinoidis Association

10. Eragrostio lehmannianae-Hippobrometum pauciflori Association

10.4. Eragrostio lehmannianae-Hippobrometum pauciflori enteropogono macrostachyos Subassociation

\section{Ursinio nanae-Myrothamnion flabellifoli Alliance of Rocky Flats}

11. Ursinio nanae-Myrothamnetum flabellifoli Association

11.1. Ursinio nanae-Myrothamnetum flabellifoli euphorbietosum cooperi Subassociation

11.2. Ursinio nanae-Myrothamnetum flabellifoli xerophytosum villosae Subassociation

\section{Combreto erythrophylli-Celtion africanae Alliance of Rocky Refugia}

12. Acacio ataxacanthae-Celtidetum africanae Association

12.1. Acacio ataxacanthae-Celtidetum africanae clausenetosum anisatae Subassociation

12.2. Acacio ataxacanthae-Celtidetum africanae acacietosum galpinii Subassociation

13. Andrachno ovalis-Allophylletum transvaalensis Association

\section{Plant community descriptions}

The Hippobromus pauciflorus-Rhoicissus tridentata Rock Outcrop Vegetation is largely restricted to the slopes and plateaus of undulating ultramafic hills. Surface rocks are predominant and abundant in these habitats, with rock percentage varying from $25 \%$ on the rocky flats to more than $50 \%$ in the rocky refugia. The vegetation can structurally be classified into forest/woodland (rocky refugia), woodland/thicket (rocky outcrops and ridges) and herbland (rocky flats) (Edwards 1983). The rock habitats of Sekhukhuneland, like those in other parts of the world (Madulid \& Agoo 1995), constitute an important feature which occurs in islands differing significantly from surrounding areas.

\section{Setario lindenbergianae-Crotion gratissimi all. nova hoc loco}

Nomenclatural type: Setario lindenbergianae-Crotonetum gratissimi (holotypus), Association 2 described in this paper. This proposed alliance is floristically related to the Croton gratissimus-Setaria lindenbergiana Woodland of Van der Meulen (1979).

Species group D (Table 1).

Environmental data: the vegetation of this alliance of rocky outcrops is a thicket or woodland. It is found on all aspects of gently sloped $\left(1-5^{\circ}\right)$ rock intrusions on midslopes, scarps and occasionally in valleys (Table 3 ). Soil forms are shallow and rocky. The soil surface is covered by $60-90 \%$ of rock with a large average diameter of 2.5-8 m (Table 3).

Diagnostic taxa: the trees Ficus abutilifolia, Homalium dentatum, Pouzolzia mixta and Vepris reflexa and the herbaceous shrubby climbers Asparagus buchananii, A. intricatus and Rhoicissus sekhukhuniensis.

Dominant/prominent taxa: trees are Croton gratissimus and Maytenus undata, the dominant grass is Panicum deustum and frequently occurring herbaceous taxa include the forb Commelina africana, the fern Pellaea calomelanos and the succulent Sarcostemma viminale.

Notes on floristic diversity: floristic links with the rest of the data set are visible in species groups $\mathrm{K}, \mathrm{Z}$ and $\mathrm{AG}$ (Table 1). These few and weak links support the proposal of this major group as an alliance. The mean number of species encountered per sample plot in this group is 29 , with a total number of 107 plant taxa (13 relevés) (Table 3 ). There are 16 plant taxa of conservation value, ten are SCPE endemics and six are SCPE near-endemics. One of the endemics, Euphorbia sekukuniensis, is a Red Data List taxon assessed as Rare (Table 2). Eight endemics of conservation value are restricted to this community of the SCPE. 


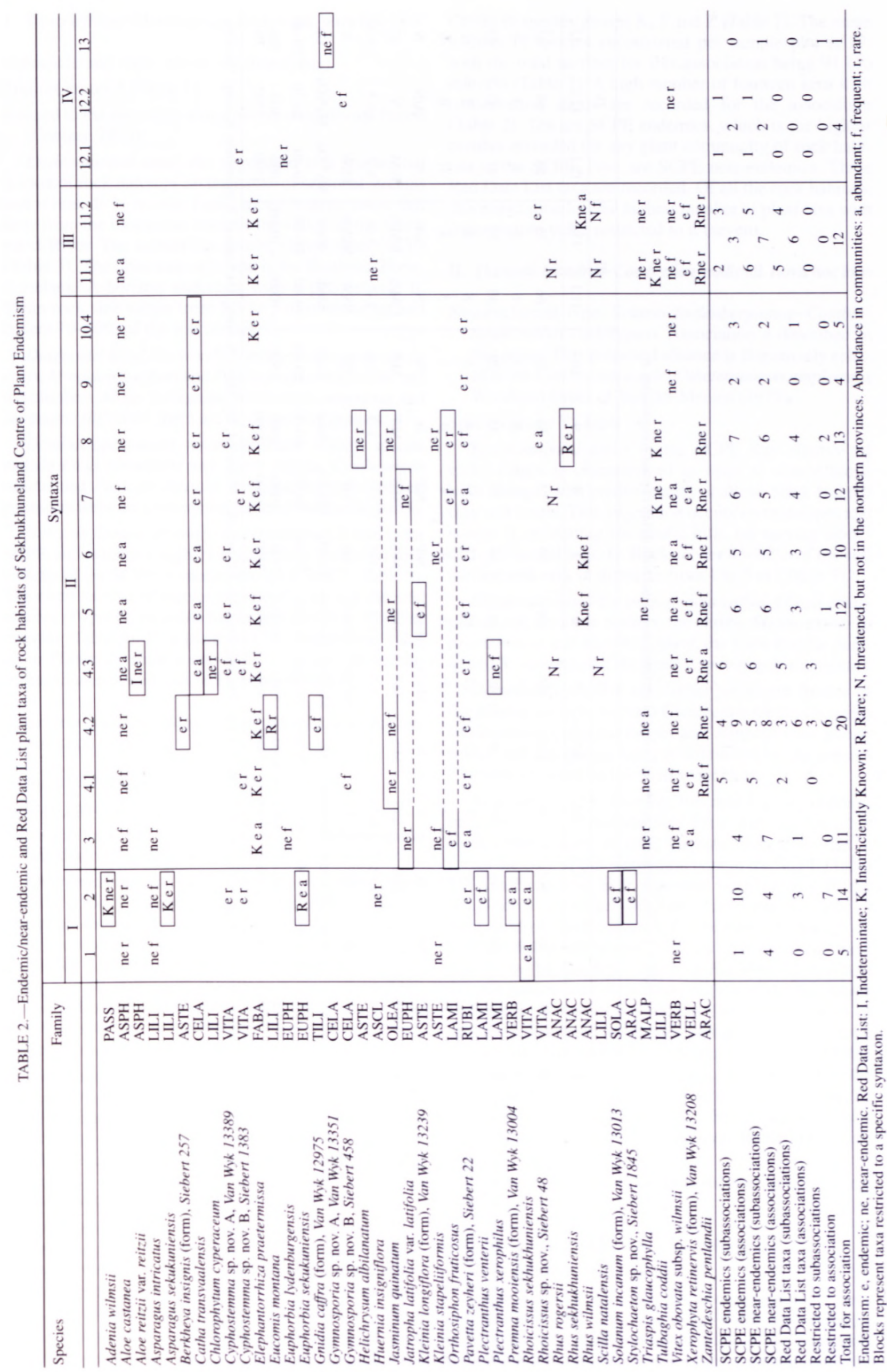




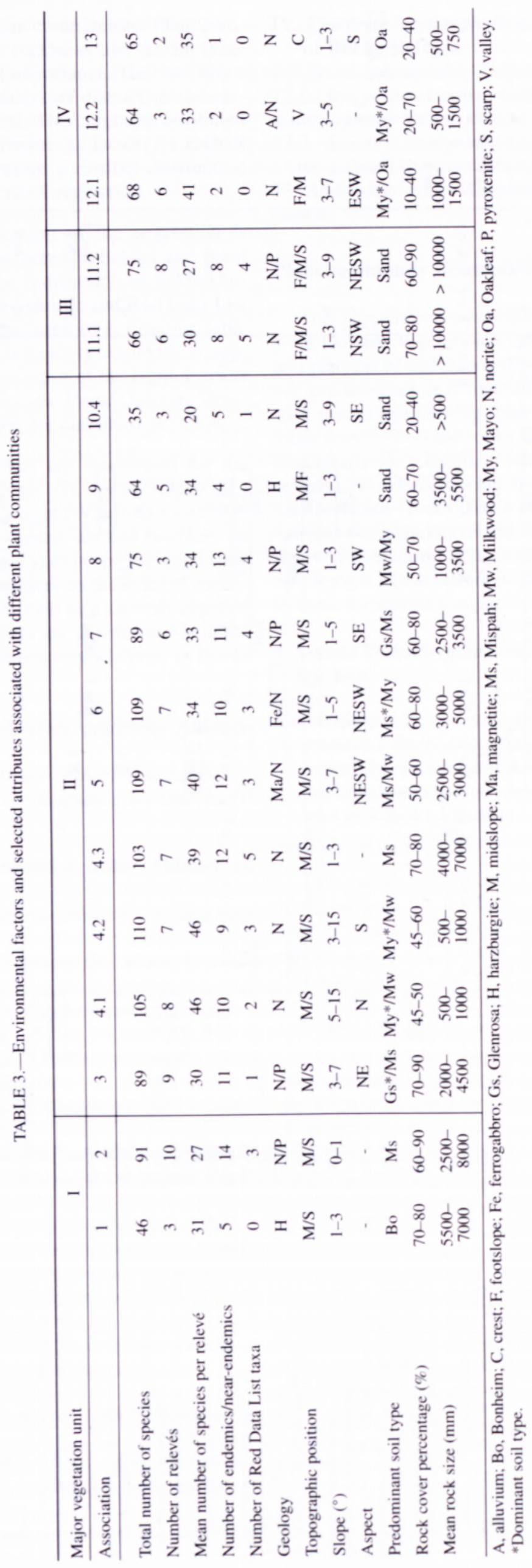


1. Vepro reflexae-Mimusopetum zeyheri ass. nova hoc loco

Nomenclatural type: relevé 190 (holotypus).

Species group A (Table 1).

Related to the Ilex mitis-Pittosporum viridiflorum Forest (Coetzee 1975).

Environmental data: the vegetation is a sparse, tall thicket of rock outcrops on the banks of seasonal streams and rivers. It is mostly found along watercourses that flow from the mountains towards the valley of the Steelpoort River. The habitat has gentle, sloped sides $\left(1-3^{\circ}\right)$ (Table 3). The dominant soil type is the Bonheim Form, a melanic A-horizon underlain with a pedocutanic B. Mean rock size varies from 5.5 to $7 \mathrm{~m}$ in diameter and covers $70-80 \%$ of the soil surface.

Diagnostic taxa: the woody species Heteropyxis natalensis, Mimusops zeyheri and Pittosporum viridiflorum and the climbers Abrus laevigatus, Rhoicissus tomentosa and Secamone filiformis; there are no diagnostic grasses.

Dominant/prominent taxa: dominant woody species include Ficus abutilifolia and Vepris reflexa. Cymbopogon validus and Panicum deustum are common grass species: prominent forbs are Orthosiphon labiatus and Ruellia patula.

Notes on floristic diversity: this community is rare in the SCPE, and exhibits a slight floristic affinity with other rock habitats of the SCPE in species groups $\mathrm{K}$ and Z (Table 1). The mean number of species per relevé is 31 , and the total number of species recorded for the association is 46 (three relevés) (Table 3 ). Five plant taxa of conservation value occur (Table 2), namely one SCPE endemic, Rhoicissus sekhukhuniensis, and four SCPE near-endemics.

2. Setario lindenbergianae-Crotonetum gratissimi ass. nova hoc loco

Nomenclatural type: relevé 195 (holotypus).

Species group B (Table 1).

Related to the Croton gratissimus-Setaria lindenbergiana Woodland (Van der Meulen 1979).

Environmental data: the vegetation is a sparse, short thicket on rocky outcrops in the Steelpoort River Valley. The plant community is associated with exposed norite or pyroxenite outcrops on level to gently sloped $\left(0-1^{\circ}\right)$ midslopes and scarps of hills. Surface rock cover percentage is $60-90 \%$, with the stacked exposed boulders reaching diameters between 2.5 and $8 \mathrm{~m}$ (Table 3 ). The dominant soil type is the Mispah Form, indicating very shallow soils over rock.

Diagnostic taxa: trees/shrubs include Commiphora marlothii, Euphorbia sekukuniensis, Nuxia congesta, Prenna mooiensis and Steganotaenia araliacea; woody forbs are Abutilon pycnodon, Ruttya ovata and Turraea obtusifolia, and the succulents Cyphostemma sulcatum and Tetradenia brevispicata; Stylochaeton sp. nov. (Siebert 1332) is an undescribed taxon and a neo-endemic of the SCPE.

Dominant/prominent taxa: Andropogon schirensis, Cymbopogon excavatus, Eragrostis nindensis and Panicum deustum are the dominant grasses; other prominent plants are the woody species Barleria rotundifolia, Combretum molle, Croton gratissimus and Maytenus undata.

Notes on floristic diversity: this plant community exhibits a slight floristic link with the rocky ridges of the
Centre in species groups $\mathrm{K}, \mathrm{T}$ and $\mathrm{Z}$ (Table 1). The mean number of species encountered per sample plot is 27 , with the total number for this association being 91 (10 relevés) (Table 3). A high number of fourteen taxa with conservation status are recorded for the association (Table 2). Ten are SCPE endemics, which is the highest number recorded for any plant community of rock habitats in the SCPE. Four are SCPE near-endemics. Three Red Data List taxa are recorded. Of all the rock habitats, this association has the highest number of plant taxa with conservation value restricted to it (seven).

\section{Themedo triandrae-Combretion mollis all. nova hoc loco}

Nomenclatural type: Setario lindenbergianae-Combretetum mollis (holotypus), Association 4 described in this paper. This proposed alliance is floristically related to the Combretum molle-Diheteropogon amplectens Woodland Order of Van der Meulen (1979).

Species group T (Table 1).

Environmental data: in the SCPE this alliance of rocky ridges is characterized as open to closed moist bush clumps, with predominantly shallow, black and red clay soil forms. This vegetation occurs on midslopes and scarps of undulating ultramafic hills, on varying slopes of $1-15^{\circ}$ on all aspects. Rocks cover $45-80 \%$ of the soil surface and vary in diameter from 1 to $5 \mathrm{~m}$ (Table 3 ).

Diagnostic taxa: the trees Acacia caffra, Olinia emarginata and Scolopia zeyheri, the shrubs Elephantorrhiza praetermissa and Pavetta zeyheri, the forbs Ruellia patu$l a$ and $R$. stenophylla; the grass Cymbopogon excavatus.

Dominant/prominent taxa: other prominent species of the alliance include the trees Combretum molle, Cussonia transvaalensis, Euclea crispa and Hippobromus pauciflorus, and the ground layer is dominated by the grasses Themeda triandra and Setaria sphacelata.

Notes on floristic diversity: this major group is dominant and floristic relationships exist with all the other plant communities of rock habitats, indicating that it forms the core of this vegetation type in the SCPE (Table 1). Associations 4 to 9 represent bush clumps in the Brachiario serratae-Melhanietum randii Rocky Grassland of the Roossenekal Subcentre (Siebert et al. 2002d) and Associations 3, 5 and 10 represent bush clumps in the Loudetio simplicis-Eucleion linearis and Setario sphacelatae-Acacietum caffrae of the Steelpoort Subcentre (Siebert et al. 2002b). The mean number of species encountered per sample plot is \pm 35 , and the total number of plant species is 150 taxa (62 relevés) (Table 3 ). Thirty-one taxa of conservation value are part of the proposed alliance, and 13 are restricted to it (Table 2). Thirteen SCPE endemics and 15 SCPE near-endemics were recorded. Nine taxa are listed on the Red Data List.

3. Grewio monticolae-Elephantorrhizetum praetermissae ass. nova hoc loco

Nomenclatural type: relevé 130 (holotypus).

Species group E (Table 1).

Environmental data: this association represents bush clumps on rocky ridges on warm north and northeast aspects of norite and pyroxenite hills in the Steelpoort Subcentre. It occurs on midslopes and scarps on red loam 
soils of the Glenrosa and Mispah Forms. It covers gentle to moderate sloped areas $\left(3-7^{\circ}\right)$. Rock cover on the surface is $70-90 \%$, with rocks reaching $2-4.5 \mathrm{~m}$ in diameter (Table 3).

Diagnostic taxa: herbaceous taxa include forbs such as the herbs Aspilia mossambicensis and Orthosiphon fruticosus and the succulent Kleinia stapeliiformis; grasses are Aristida rhiniochloa and Sporobolus stapfianus; woody species are Englerophytum magalismontanum and Grewia monticola.

Dominant/prominent taxa: important dominant taxa are shrubs, namely Elephantorrhiza praetermissa, Hippobromus pauciflorus, Pavetta zeyheri and Xerophyta retinervis (form); grasses such as Aristida transvaalensis, Panicum deustum and Themeda triandra are dominant.

Notes on floristic diversity: this association is not strongly linked with the other associations of its group and is probably more related to the Englerophytum magalismontanum-Acacia caffra Mountain Bushveld (Winterbach et al. 2000). The mean number of species encountered per sample plot is 30 , with a total number of 89 plant taxa (nine relevés) (Table 3). Four SCPE endemics, seven SCPE near-endemics and one Red Data List taxon are present in this association (Table 2). None of the 11 taxa of conservation value are restricted to it.

4. Setario lindenbergianae-Combretetum mollis ass. nova hoc loco

Nomenclatural type: relevé 41 (holotypus).

Species group $\mathbf{J}$ (Table 1).

Related to the Setaria lindenbergiana-Combretum molle Woodland Community (Bredenkamp et al. 1994).

Environmental data: this association represents bush clumps on moderate to steep-sloped $\left(1-15^{\circ}\right)$ midslopes and scarps of norite (sometimes pyroxenite) hills. It occurs on deeper red and black clay soils of the Mayo and Milkwood Forms, which are interspersed with shallow gravel soils of the Glenrosa Form. Rock cover is $45-80 \%$ of the soil surface with sizes between 0.5 and 7 $\mathrm{m}$ in diameter (Table 3 ).

Diagnostic taxa: herbaceous taxa include forbs such as the herbs Commelina benghalensis and Orthosiphon labiatus and the succulent Tetradenia riparia; the grass is Eragrostis chloromelas; woody species are Cussonia paniculata, Dombeya rotundifolia, Ficus ingens, Grewia occidentalis and Seemannaralia gerrardii.

Dominant/prominent taxa: important dominant taxa are trees, namely Allophyllus africanus, Apodytes dimidiata, Croton gratissimus, Combretum molle and Cussonia transvaalensis; grasses such as Cymbopogon excavatus, Setaria lindenbergiana, S. sphacelata and Themeda triandra are dominant.

Notes on floristic diversity: the association has a species combination typical for rocky outcrops in species group K, shared with Associations 1, 2 and 3 (Table 1). In species group $\mathrm{P}$ it shares a species combination typical of rocky ridges with Association 5 to 8 (Table 1). This community is also unique in that it shares forest species with Associations 12 and 13 in species group AF (Table 1). The mean number of species encountered per sample plot is \pm 44 , the highest mean number recorded per relevé for any of the major vegetation units of rock habitats in the SCPE. A total number of 122 plant taxa were recorded ( 22 relevés) (Table 3 ) of which 20 have conservation status (the highest number for any association of SCPE rocky habitats). Nine SCPE endemics, eight nearendemics (the highest number for rocky habitats) and six Red Data List taxa (the highest number for rocky habitats) are recorded for this association (Table 2). A high number of six taxa is restricted to it.

\subsection{Setario lindenbergianae-Combretetum mollis cathe-} tosum edulis subass. nova hoc loco

Nomenclatural type: relevé 41 (holotypus).

Species group F (Table 1).

Environmental data: this sub-association represents dry, warm bush clumps on northern aspects of hills. It occurs on deeper red and black clay soils of the Mayo and Milkwood Forms and lies on moderately sloped $\left(5-15^{\circ}\right)$ midslopes and scarps. Rock cover on the surface is $45-50 \%$, with rock sizes between 0.5 and $1 \mathrm{~m}$ in diameter (Table 3 ).

Diagnostic taxa: trees include Acacia robusta, Catha edulis, Euphorbia ingens, Ficus craterostoma, Schrebera alata and Sclerocarya birrea; herbaceous taxa include the forbs Commelina erecta, Helichrysum intricatum, $\mathrm{Hy}$ poestes aristata and Sanseviera hyacinthoides; the grasses are Aristida canescens and Eragrostis heteromera.

Dominant/prominent taxa: conspicuous dominant taxa are trees such as Acacia ataxacantha, Hippobromus pauciflorus and Ziziphus mucronata, and grasses such as Panicum deustum, Setaria sphacelata and Themeda triandra.

Notes on floristic diversity: the subassociation has a grassland-savanna species combination in species group $\mathrm{H}$ which it shares with Subassociation 4.2 (Table 1). The mean number of species encountered per sample plot is 46 , together with Subassociation 4.2, the highest number recorded per relevé for any of the vegetation units of rock habitats. A total number of 105 plant taxa were recorded (eight relevés) (Table 3 ). Five SCPE endemics, of which two are Red Data List taxa namely Elephantorrhiza praetermissa and Zantedeschia pentlandii, and five near-endemics are found in this subassociation (Table 2).

\subsection{Setario lindenbergianae-Combretetum mollis diospy- retosum nitensis subass. nova hoc loco}

Nomenclatural type: relevé 81 (holotypus).

Species group G (Table 1).

Environmental data: see description of Subassociation 4.1. This subassociation represents bush clumps of rocky ridges, which is restricted to grassland on moist. cool southern aspects (Table 3 ).

Diagnostic taxa: predominantly woody ones, namely Buddleja auriculata, B. salviifolia, Diospyros lycioides subsp. nitens, Jasminum quinatum, Rhus rigida and Triaspis glaucophylla; the only diagnostic forb is Pupalia lappacea.

Dominant/prominent taxa: conspicuous woody species are Apodytes dimidiata, Combretum molle, Hippobromus pauciflorus and Rhoicissus tridentata; grasses include Heteropogon contortus, Panicum deustum, Setaria sphacelata and Themeda triandra. 
Notes on floristic diversity: Species group H (Table 1) shows a strong floristic connection with Subassociation 4.1 due to the similar geographical distribution, just on different aspects of the same hills. The mean number of species encountered per sample plot is 46 , the highest mean number recorded per relevé in the data set. The total number of plant species for this subassociation is 110 (seven relevés), the richest diversity of species recorded for any rock habitat in the SCPE (Table 3). Of the 10 taxa of conservation value in this subassociation, four are SCPE endemics and five are SCPE near-endemics. Of these, three are Red Data List taxa (Table 2). Three taxa are restricted to the subassociation, namely Berkheya insignis (endemic form), Eucomis montana (Rare in the Red Data List) and Gnidia caffra (endemic form).

\subsection{Setario lindenbergianae-Combretetum mollis aloetum aculeatae subass. nova hoc loco}

Nomenclatural type: relevé 20 (holotypus).

Species group I (Table 1).

Environmental data: a subassociation dominated by a dense herbaceous cover on level ridges situated on midslopes and scarps of grass-covered norite hills. It occurs on red clay soils of the Mispah Form, with the soil surface covered by $70-80 \%$ rock of a relatively large size of 4 to $7 \mathrm{~m}$ in diameter (Table 3 ).

Diagnostic taxa: the fern Cheilanthes hirta; the succulents Aloe aculeata, Kalanchoe rotundifolia, Plectranthus xerophilus and Sansevieria aethiopica; the forbs, Gloriosa superba and Tripteris auriculata, dominate the community; two undescribed Cyphostemma species; Sporobolus ioclados and Trachypogon spicatus are the grasses.

Dominant/prominent taxa: woody species are the trees Barleria rotundifolia, Catha transvaalensis, Croton gratissimus, Kirkia wilmsii and the small shrub Chrysanthemoides monilifera; conspicuous grasses include Andropogon schirensis and Eragrostis nindensis.

Notes on floristic diversity: a noteworthy floristic relationship exists with Association 2 in species group C (Table 1), which can be ascribed to occurrence on the scarps of hills. The mean number of species encountered per sample plot is 39 and the total number for the subassociation is 103 (seven relevés) (Table 3). Six SCPE endemics, six near-endemics and five Red Data List taxa are recorded (Table 2). Of these 14 taxa of conservation value, three near-endemics are restricted to it, namely Aloe reitzii var. reitzii (Indeterminate in Red Data List), Chlorophytum cyperaceum and Plectranthus xerophilus.

\section{Brachiario serratae-Viticetum wilmsii ass. nova hoc loco}

Nomenclatural type: relevé 71 (holotypus).

Species group L (Table 1).

Environmental data: this association is a dry bush clump of any aspect, situated on exposed iron-rich norite and magnetite ridges, on midslopes and scarps of hills. It occurs on red and black clay soils of the Mispah Form (ortic A-horizon) and Milkwood Form (melanic A-horizon) underlain by hard rock. The soil surface is covered by $50-60 \%$ rock, of an average size of $2.5-3 \mathrm{~m}$ in diameter (Table 3). Slope of the habitat is usually moderate $\left(3-7^{\circ}\right)$.

Diagnostic taxa: dominant species are forbs such as Rhynchosia spectabilis, Ruellia cordata and Pearsonia aris- tata; the succulent Aloe verecunda; the sedge Bulbostylis burchellii and the grasses Aristida junciformis, Brachiaria serrata and Tristachya rehmannii.

Dominant/prominent taxa: woody species are Apodytes dimidiata, Catha transvaalensis, Olea capensis subsp. enervis and Vitex obovata subsp. wilmsii; conspicuous taxa include Aloe castanea and Sphedamnocarpus pruriens.

Notes on floristic diversity: the community has a marked floristic grassland affinity in species group X with Association 11 (Table 1). The mean number of species encountered per sample plot is 40 , with the total number for this association being relatively high at 109 species (seven relevés) (Table 3). Six SCPE endemics and six SCPE nearendemics, of which three are Red Data List taxa, were recorded (Table 2).

6. Cymbopogono validi-Brachylaenetum rotundatae ass. nova hoc loco

Nomenclatural type: relevé 51 (holotypus).

Species group M (Table 1).

Environmental data: this association represents bush clumps in grassland on all aspects of hills with norite and ferrogabbro rocky ridges. It usually occurs at higher altitudes than the other associations, and is found on midslopes and scarps on red clay soils of the Mayo and Mispah Forms. It lies on gently sloped areas $\left(1-5^{\circ}\right)$. Rock cover on the surface is $60-80 \%$, with rocks reaching an average size of $3-5 \mathrm{~m}$ in diameter (Table 2).

Diagnostic taxa: herbaceous taxa include the forbs Pachycarpus transvaalensis, Pearsonia sessilifolia, Rhynchosia hirta, Senecio oxyriifolius and Solanum supinum; woody species include the tree Brachylaena rotundata, the shrub Grewia villosa and the bushy Felicia filifolia.

Dominant/prominent taxa: important dominant taxa are trees such as Catha transvaalensis, Olea capensis subsp. enervis and Ziziphus mucronata, and grasses such as Cymbopogon excavatus, $C$. validus, Heteropogon contortus and Themeda triandra.

Notes on floristic diversity: no noteworthy floristic links are evident with associations outside the major group (alliance). The mean number of species encountered per sample plot is 34 , with a high total number of 109 plant taxa (seven relevés) (Table 3). Five SCPE endemics and five near-endemics, of which three are Red Data List taxa, are found in this association (Table 2).

\section{Aloo pretoriensis-Xerophytetum retinervis ass. nova hoc loco}

Nomenclatural type: relevé 136 (holotypus).

Species group N (Table 1).

Related to the Zantedeschio pentlandi-Aloetum castaneae (Siebert et al. 2002d).

Environmental data: this association is an open, sparse bush clump of norite and pyroxenite ridges, on midslopes and scarps of hills. It occurs on black and red clay soils of the Glenrosa and Mispah Forms on cool south and southeast aspects. The soil surface is covered by $60-80 \%$ rock of an average size of $2.5-3.5 \mathrm{~m}$ in diameter (Table 3). Slope of the habitat is usually $1-5^{\circ}$.

Diagnostic taxa: dominated by forbs such as Convolvulus sagittatus, Dalechampia galpinii, Gnidia varia- 
bilis, Jatropha latifolia and Justicia protracta; the diagnostic shrub is Gymnosporia buxifolia; the succulent Aloe pretoriensis.

Dominant/prominent taxa: woody species include the shrubs Hippobromus pauciflorus, Pavetta sp. nov. and Vitex obovata subsp. wilmsii; important conspicuous grasses include Aristida transvaalensis, Cymbopogon excavatus and Themeda triandra.

Notes on floristic diversity: the association has several floristic relationships with the rest of the data set. The mean number of species encountered per sample plot is 33 , with 89 species the total number for this association (six relevés) (Table 3 ). Of the 12 taxa of conservation value, no taxa are restricted to it. Six SCPE endemics and five SCPE near-endemics were recorded, of which four are Red Data List taxa (Table 2).

\section{Tephrosio purpureae-Rhoicissetum tridentatae ass. nova hoc loco}

Nomenclatural type: relevé 320 (holotypus).

Species group O (Table 1).

Environmental data: this vegetation type is a typical ecotone between Brachiario serratae-Melhanietum randii Rocky Grassland and Themedo triandrae-Combretion mollis of Rocky Ridges in the southern region of the SCPE. It is open shrubland in moist grassland on midslopes and scarps of undulating norite or pyroxenite hills. The habitat has a level slope of $1-3^{\circ}$, restricted to south and west aspects. Soils are typical red and black clays of the Mayo and Milkwood Forms. Rock size is $1-3.5 \mathrm{~m}$ in diameter and cover $50-70 \%$ of the soil surface (Table 3 ).

Diagnostic taxa: the grassland forb species Dioscorea sylvatica, Helichrysum albilanatum, Rhynchosia minima, Tephrosia purpurea and Zormia linearis; the grasses Digitaria argyrograpta, Eragrostis curvula and Hyparrhenia filipendula; the trees Canthium mundianum, Rhus sekhukhuniensis and Rhus discolor (suffrutex).

Dominant/prominent taxa: the trees/shrubs Euclea crispa, Hippobromus pauciflorus, Olea capensis subsp. enervis, Rhoicissus tridentata and $R$. sp. nov.; the grass Cymbopogon excavatus.

Notes on floristic diversity: this association's floristic relationships are typical for the alliance (Table 1). The mean number of species encountered per sample plot is 34 and the total number of plant species for this association is 75 (three relevés) (Table 3). A high number of taxa of conservation value are found in this association (13), and of these seven are SCPE endemics and six are SCPE near-endemics. Four of these are Red Data List taxa (Table 2). Two taxa with conservation status are restricted to the association, namely the near-endemic Helichrysum albilanatum and the Rare (R) endemic Rhus sekhukhuniensis.

9. Sporobolo fimbriati-Rhamnetum prinoidis ass. nova hoc loco

Nomenclatural type: relevé 4 (holotypus).

Species group Q (Table 1).

Environmental data: this is a distinct association of moist riverbank thicket on raised banks of mountain streams in the valleys between undulating grass-covered norite and pyroxenite hills. It lies on a gentle slope of $1-3^{\circ}$. Soils are characteristically a moist 'humus-rich' sandy loam on a rocky substrate. Approximately 60-70\% of the soil surface is covered by rocks, with a size of $3.5-5.5 \mathrm{~m}$ in diameter (Table 3 ).

Diagnostic taxa: tree species are prominent, namely Cassinopsis ilicifolia, Leucosidea sericea and Rhamnus prinoides; forbs are Freesia laxa, Kalanchoe paniculata and Thunbergia atriplicifolia; a sedge Scleria dieterlenii and the grass Sporobolus fimbriatus.

Dominant/prominent taxa: other important trees are Chionanthus foveolatus and Olinia emarginata; the grasses are Aristida transvaalensis, Cymbopogon validus, Eragrostis racemosa and Panicum deustum.

Notes on floristic diversity: the association follows the floristic affinities of the alliance, but is characterized by the absence of the taxa in species group $\mathrm{P}$ and $\mathrm{Y}$ due to the presence of moist, lowland soils (Table 1). The mean number of species encountered per sample plot in this association is 34 , with the total number of 64 plant species (five relevés) (Table 3 ). Four taxa of interest occur in this association, namely two SCPE endemics and two near-endemics (Table 2).

10. Eragrostio lehmannianae-Hippobrometum pauciflori Association (Siebert et al. 2002b)

10.1. Eragrostio lehmannianae-Hippobrometum pauciflori rhoetosum batophyllae Subassociation (Siebert et al. 2002b)

10.2. Eragrostio lehmannianae-Hippobrometum pauciflori sorgetosum bicoloris Subassociation (Siebert et al. 2002b)

10.3. Eragrostio lehmannianae-Hippobrometum pauciflori eucleetosum crispae Subassociation (Siebert et al. 2002b)

10.4. Eragrostio lehmannianae-Hippobrometum pauciflori enteropogono macrostachyos subass. nova hoc loco

Nomenclatural type: relevé 334 (holotypus).

Species group S (Table 1).

Environmental data: this vegetation type represents transformed savanna on cool, south and east aspects of norite hills. It covers moderate midslopes and scarps $\left(3-9^{\circ}\right)$. The community is restricted to sandy loam soils in the northern parts of the SCPE. Approximately $20-40 \%$ of the soil surface is covered by rocks, with a diameter of $>500 \mathrm{~mm}$ (Table 2).

Diagnostic taxa: the shrubby Psiadia punctulata; the grasses Cynodon dactylon, Enteropogon macrostachys, Eragrostis lehmanniana and Panicum coloratum.

Dominant/prominent taxa: prominent trees are Acacia caffra, Euclea crispa, Hippobromus pauciflorus and Rhoicissus tridentata.

Notes on floristic diversity: no clear-cut floristic links exist with other plant communities of rocky ridges and it is characterized by the absence of the taxa of rocky habitats listed in species group Y (Table 1). Intense harvesting of wood and overgrazing of the veld is indicated by the low frequency of taxa in species groups $\mathrm{T}, \mathrm{Z}$ and $\mathrm{AG}$ 
(Table 1). The mean number of species encountered per sample plot is 20 and the total number is 35 (three relevés) (Table 3). These numbers are the lowest recorded for the rock habitats of the SCPE. None of the five plant taxa with conservation value are restricted to it and comprise three SCPE endemics and two near-endemics, of which one is a locally common Red Data List taxon (Table 2).

\section{Ursinio nanae-Myrothamnion flabellifoli all. nova hoc loco}

Nomenclatural type: Ursinio nanae-Myrothamnetum flabellifoli (holotypus), Association 11 described in this paper. This proposed alliance is floristically related to the Myrothamnus flabellifolius-Ursinia nana Community of Smit et al. (1997).

Species group W (Table 1).

Environmental data: alliance of rocky flats on footslopes, midslopes and scarps of predominantly ultramafic hills and to a lesser extent also hills of the Transvaal Sequence. The habitat occurs on all aspects and is gently to moderately sloped $\left(1-9^{\circ}\right)$. Approximately $60-90 \%$ of the soil surface is covered by flat rocks exposed at ground level with a relatively large diameter of $>10 \mathrm{~m}$ (Table 3). Soils are sandy and 'humus-rich' in hollows and fissures in the bedrock.

Diagnostic taxa: see description of Association 11.

Dominant/prominent taxa: see description of Association 11.

Notes on floristic diversity: a strong floristic affinity exists with the alliance of rocky ridges, which is confirmed by species groups $\mathrm{Y}$ and $\mathrm{Z}$ (Table 1). The mean number of species encountered per sample plot is \pm 29 , and the total number of plant species is 83 taxa ( 14 relevés) (Table 3). This alliance has 12 plant taxa of conservation value, of which three are SCPE endemics and seven nearendemics. Six Red Data List taxa occur. Together with Association 4, this is the highest number of Red Data List taxa recorded for rock habitats in the SCPE. None of these taxa are restricted to the proposed alliance.

\section{Ursinio nanae-Myrothamnetum flabellifoli ass. nova hoc loco}

Nomenclatural type: relevé 35 (holotypus).

Species group W (Table 1).

Related to the Myrothamnus flabellifolius-Ursinia nana Community (Smit et al. 1997).

Environmental data: the vegetation structure is shrubby and grassy and widespread throughout hillsides of the study area and variations of this association are probably widespread along the north-eastern escarpment. It occurs on all aspects of footslopes, midslopes and scarps. It lies on gentle to moderate slopes $\left(1-9^{\circ}\right)$ and is found predominantly on moist, 'humus-rich' sandy soils. Approximately $60-90 \%$ of the soil surface is covered by rocks. with a mean size of $>10 \mathrm{~m}$ in diameter (Table 3 ).

Diagnostic taxa: dominated by forbs including Crassula swaziensis, Craterostigma wilmsii, Oldenlandia herbacea and Pearsonia cajanifolia; grasses are Aristida adscensionis, Eragrostis capensis, E. pseudosclerantha and Melinis repens.
Dominant/prominent taxa: the fern Pellaea calomelanos; the shrubby Xerophyta retinervis; the succulents Aloe castanea and Crassula sarcocaulis; the grasses Aristida transvaalensis and Eragrostis racemosa.

Notes on floristic diversity: the same as the alliance. Association is common throughout the Bankenveld.

\subsection{Ursinio nanae-Myrothamnetum flabellifoli euphor- bietosum cooperi subass. nova hoc loco}

Nomenclatural type: relevé 35 (holotypus).

Species group U (Table 1).

Environmental data: widespread throughout the Roossenekal Subcentre on north, south and west aspects of footslopes, midslopes and scarps of undulating norite hills. It lies on gentle slopes $\left(1-3^{\circ}\right)$ and is found predominantly on sandy soils. Approximately $70-80 \%$ of the soil surface is covered by rocks, with a mean diameter of $>10 \mathrm{~m}$ (Table 3 ).

Diagnostic taxa: herbaceous species are the fern Cheilanthes involuta, the geophyte Stylochaeton natalensis, and the forbs Dioscorea dregeana and Orthosiphon amabilis; trees/shrubs include Vangueria infausta and a short-stemmed form of the succulent Euphorbia cooperi; grasses are Aristida scabrivalvis and Microchloa caffra.

Dominant/prominent taxa: the succulent Crassula swaziensis and woody Myrothamnus flabellifolius are dominant forbs; prominent shrubs are Euclea crispa, Mundulea sericea and Rhoicissus tridentata; frequently occurring grasses are Aristida transvaalensis, Eragrostis pseudosclerantha, E. racemosa and Heteropogon contortus.

Notes on floristic diversity: a strong floristic relationship exists with Subassociation 11.2 in species group W and Association 5 species group X (Table 1). The mean number of species encountered per sample plot is 30 and the total number of plant species is 66 taxa (six relevés) (Table 3). None of the ten plant taxa of conservation value, namely two SCPE endemics, six near-endemics and five Red Data List taxa, are restricted to the subassociation (Table 2).

\subsection{Ursinio nanae-Myrothamnetum flabellifoli xerophy- tosum villosae subass. nova hoc loco}

Nomenclatural type: relevé 97 (holotypus).

Species group V (Table 1).

Environmental data: this community is widespread throughout the SCPE. It occurs on rocky flats with 'humus-rich', sandy soils. It covers moderately sloped footslopes, midslopes and scarps of $3-9^{\circ}$ on all aspects of undulating norite and pyroxenite hills. Approximately $60-90 \%$ of the soil surface is covered by large rocks, with a mean size of $>10 \mathrm{~m}$ in diameter (Table 3 ).

Diagnostic taxa: herbs are most diagnostic and include the fern Cheilanthes eckloniana and fern ally Selaginella dregei, the forbs Kedrostis foetidissima, Thesium burkei and Xerophyta villosa; the succulents Crassula alba, Euphorbia schinzii. Kalanchoe luciae and Kleinia longiflora; Rhus wilmsii is a woody suffrutex.

Dominant/prominent taxa: taxa of importance are the grasses Aristida transvaalensis and Melinis nerviglumis; the succulents Aloe castanea and Crassula sarcocaulis are conspicuous members. 
Notes on floristic diversity: floristic relationships are similar to that of Subassociation 11.1 (Table 1). The mean number of species encountered per sample plot is 27 and the total number of plant species is 75 taxa (eight relevés) (Table 3 ). There are nine taxa of conservation value in the subassociation, namely three SCPE endemics, five near-endemics and four Red Data List taxa (Table 2).

\section{Combreto erythrophylli-Celtion africanae (Siebert $e t$ al. 2002c)}

Species group AF (Table 1).

Environmental data: this well-documented alliance (Coetzee 1975; Van der Meulen 1979; Matthews et al. 1992) represents forests and dense woodlands in rocky refugia of the SCPE. It is a rare vegetation type and can be found on southern aspects of valleys, and mountain footslopes, midslopes and crests. The habitat is characterized by large norite boulders of minimum $2 \mathrm{~m}$ high and the mean rock diameter $\pm 0.5-2.5 \mathrm{~m}$ and covers \pm $10-70 \%$ of the soil surface. It is characterized by gentle to moderate slopes $\left(1-7^{\circ}\right)$. Soil types are a red or black clay base on unconsolidated material and include the Mayo (lithocutanic B-horizon) and the Oakleaf (neocutanic B-horizon) Forms.

Diagnostic taxa: the trees Calodendrum capense and Celtis africana, the shrub Diospyros whyteana and the succulent Aloe arborescens.

Dominant/prominent taxa: prominent taxa include the woody species Acacia ataxacantha, Allophyllus africanus, Ehretia rigida, Halleria lucida, Hippobromus pauciflorus and Ziziphus mucronata; Panicum deustum is the dominant grass.

Notes on floristic diversity: a strong floristic affinity exists with Association 4 in species group AF (Table 1), which indicates its relationship with the tall bush clumps of rocky ridges. The mean number of species encountered per sample plot is \pm 36 and the total number of plant species is 79 taxa (11 relevés) (Table 3 ). There are five taxa of conservation value associated with this major group, namely two SCPE endemics and three SCPE near-endemics (Table 2). Of these taxa, an undescribed Gymnosporia, is restricted to the alliance.

\section{Acacio ataxacanthae-Celtidetum africanae (Matthews et} al. 1992)

\subsection{Acacio ataxacanthae-Celtidetum africanae clauseneto-} sum anisatae subass. nova hoc loco

Nomenclatural type: relevé 67 (holotypus).

Species group AA (Table 1).

Environmental data: in the Roossenekal Subcentre this subassociation represents wooded rocky refugia, mostly associated with boulders around caves, in kloofs and below cliffs, or stone walls of old kraals. It is a vegetation unit on red clay soils of the Mayo and Oakleaf Forms. These units occur on footslopes and midslopes of undulating norite hills. The gentle slopes vary from $3-7^{\circ}$ and east-south-west aspects are predominant. Rock cover percentage varies from 10 to $40 \%$ and rock diameter is $1-1.5 \mathrm{~m}$ (Table 3 ),

Diagnostic taxa: trees are most dominant and include Clausena anisata, Clerodendrum glabrum, C. myricoides,
Ficus thonningi, Obetia tenax and the succulent Aloe marlothii; forbs are Abutilon austro-africanum, Cyathula cylindrica, Hermannia floribunda and Scadoxus puniceus; grasses include Brachiaria brizantha, Digitaria sanguinalis, Setaria verticillata and Urochloa mossambicensis.

Dominant/prominent taxa: important dominant taxa include the woody species Acacia ataxacantha, Allophyllus transvaalensis, Celtis africana and Diospyros whyteana, the forb Pavonia burchellii, and the grasses Panicum deustum and $P$. maximum.

Notes on floristic diversity: strong floristic links exist with Subassociation 12.2 in species group $\mathrm{AC}$ and a specific Afromontane link with Association 13 in species group AE (Table 1). Species shared with other rock habitats are few. The mean number of species encountered per sample plot is a high 41 (Table 3 ). The total number of plant species for this subassociation is 68 (six relevés). Two taxa of conservation value occurs in this subassociation, namely an undescribed endemic Cyphostemma species (Siebert 1383) and the near-endemic Euphorbia lydenburgensis.

\subsection{Acacio ataxacanthae-Celtidetum africanae acacieto-} sum galpinii subass. nova hoc loco

Nomenclatural type: relevé 182 (holotypus).

Species group AB (Table 1).

Environmental data: this vegetation type is slightly transformed woodlands of rocky banks along the larger rivers in the valleys. The habitat lies between norite outcrops on black and red clay soils derived from alluvium. It lies on gentle slopes of $3-5^{\circ}$. Soils are predominantly the Mayo and Oakleaf Forms. Approximately $20-70 \%$ of the soil surface is covered by rocks, with an average diameter of $0.5-2.5 \mathrm{~m}$ (Table 3 ).

Diagnostic taxa: the woody species Acacia galpinii, Combretum erythrophyllum, Ficus sur, Flueggea virosa. Melia azedarach (naturalized alien) and Spirostachys africana; forbs are Achyranthes aspera, Barleria obtusa. and the climbers Cardiospermum corindum and Secamone acutifolia.

Dominant/prominent taxa: Celtis africana and Schotia brachypetala are prominent trees; important dominant grasses include Panicum deustum and P. maximum.

Notes on floristic diversity: the subassociation shows the same floristic links as Subassociation 12.1 (Table 1). The mean number of species encountered per sample plot is 33 and the total number is 64 (three relevés) (Table 3 ). It has two taxa of conservation value, namely a locally common near-endemic and an undescribed endemic Gymnosporia (Siebert 458) (Table 2).

13. Andrachno ovalis-Allophylletum transvaalensis ass. nova hoc loco

Nomenclatural type: relevé 406 (holotypus).

Species group AD (Table 1).

Environmental data: this association comprises two relict Afromontane Forest patches on the summit of the Leolo Mountains ( $1800 \mathrm{~m}$ a.s.1.). It is associated with norite substrates and boulders of $2-6 \mathrm{~m}$ high. The habitat has a southern aspect and a gentle slope of $1-3^{\circ}$. Approximately $20-40 \%$ of the soil surface is covered by rocks with a mean 
diameter of 500-750 mm (Table 3), which can be up to $3 \mathrm{~m}$ high. Soil is black clay of the Oakleaf Form.

Diagnostic taxa: dominated by woody species, namely Andrachne ovalis, Gymnosporia sp. nov. (Van Wyk \& Siebert 13351), Ilex mitis, Kiggelaria africana, Prunus africana and Senna occidentalis; forbs include Polygala virgata, Senecio tamoides, Solanum aculeastrum and Urtica lobulata.

Dominant/prominent taxa: conspicuous taxa are the tree Halleria lucida, the climber Clematis brachiata and the grass Panicum deustum.

Notes on floristic diversity: strong floristic affinities exist with Association 12 in species groups $\mathrm{AE}$ and $\mathrm{AF}$ (Table 1). It also shares woodland species with Association 4 in species group AF (Table 1). However, this is not a true vegetation type of rock habitats, but due to the subsequent undersampling and existence of only two forest patches ( 2 relevés). The community is described here for lack of better placement. The mean number of species encountered per sample plot is 35 and the total number of plant species is 65 taxa (two relevés) (Table 3 ). This association has one taxon with conservation status, namely the undescribed, near-endemic Gymnosporia sp. nov. (Van Wyk \& Siebert 13351) (Table 2). Another noteworthy taxon is Nemesia zimbabwensis with its disjunct distribution shared with the Eastern Highlands of Zimbabwe. Both these taxa are restricted to the association. Its relict status gives the community special conservation significance as a rare plant community (perhaps the rarest in the SCPE).

\section{DISCUSSION}

\section{Ordination and environmental factors}

The naturally sparsely vegetated appearance of rocky habitats can be ascribed to the relatively high surface cover of rock, comprising many taxa typical for this habitat in the northern provinces of South Africa. When compared with other habitats of the SCPE (Siebert 2001), its environmental factors are relatively homogeneous. A combination of factors such as terrain type (slope), soil texture (clay/sand content) and rockiness (rock size and rock cover), affect the species composition of these plant communities. The ordination supported a gradient which is mainly the consequence of rockiness.

The scatter diagram displays the distribution of relevés along the first and second ordination axes (Figure 2 ). The vegetation units are represented as groups, their distribution on the scatter diagram corresponding with certain physical environmental conditions. The rockiness, slope and soil texture determine a definite gradient that is depicted by both the first (eigen value $=0.669$ ) and second axis (eigen value $=0.456$ ). Rockiness, slope and soil texture determine the moisture retention and drainage of the habitat. The gradient on the $\mathrm{x}$-axis expresses rock cover as a percentage of the soil surface, with the left extreme of the scatter diagram representing rocky flats with its continuous layers of rock at the soil surface and the right depicting the large boulders with large areas of open soil between them, which are typical for rocky refugia. On the $y$-axis, the gradient indicates higher moisture availability over the long term at the top of the diagram, because clayey soils on moderate slopes with large areas covered with rock remain moist over a longer period. Steep slopes with sandy soils and low rock cover dry out quickly and are at the bottom of the diagram. The $\mathrm{x}$-axis also exhibits a gradient with deep soils at the right and shallow soils at the left.

All these gradients correlate closely with each other and have a strong influence on the vegetation structure and species composition. The three most dominant and conspicuous taxa of each growth form (trees/shrubs/suffrutices, forbs/sedges and grasses) are given for each of the four major vegetation types (alliances) depicted in the scatter diagram (Table 4).

A vegetation key is presented to aid with the identification of the various plant communities (Table 5). The definitions are broad indications of typical groups and should be seen as a guideline. A diagnostic characteristic of the vegetation or habitat is given, followed by a most diagnostic and a most visual species of the plant community. The first species is restricted to the specific com-

TABLE 4.-Nine most dominant and conspicuous plant taxa of each of major vegetation types depicted in DECORANA scatter diagram

\begin{tabular}{|c|c|c|c|}
\hline \multirow{2}{*}{ Major vegetation type (Alliance) } & \multicolumn{3}{|c|}{ Growth form } \\
\hline & Trees/shrubs & Forbs/sedges & Grasses \\
\hline \multirow[t]{3}{*}{ 1. Setario lindenbergianae-Crotion gratissimi } & Croton gratissimus & Asparagus intricatus & Andropogon schirensis \\
\hline & Ficus abutilifolia & Rhoicissus sekhukhuniensis & Panicum deustum \\
\hline & Vepris reflexa & Sarcostemma viminale & Setaria lindenbergiana \\
\hline \multirow[t]{3}{*}{ II. Themedo triandrae-Combretion mollis } & Combretum molle & Cyphostemma woodii & Cymbopogon excavatus \\
\hline & Hippobromus pauciflorus & Gerbera jamesonii & Setaria sphacelata \\
\hline & Pavetta zeyheri & Rhoicissus tridentate & Themeda triandra \\
\hline \multirow[t]{3}{*}{ III. Ursinio nanae-Myrothamnion flabellifoli } & Aloe castanea & Crassula sarcocaulis & Aristida transvaalensis \\
\hline & Mundulea sericea & Myrothamnus flabellifolia & Eragrostis pseudosclerantha \\
\hline & Xerophyta retinervis & Ursinia nana & Melinis nerviglumis \\
\hline \multirow[t]{3}{*}{ IV. Combreto erythrophylli-Celtion africanae } & Celtis africana & Clematis brachiata & Panicum deustum \\
\hline & Combretum erythrophyllum & Lippia javanica & Panicum maximum \\
\hline & Diospyros whyteana & Pavonia burchelii & Urochloa mosambicensis \\
\hline
\end{tabular}




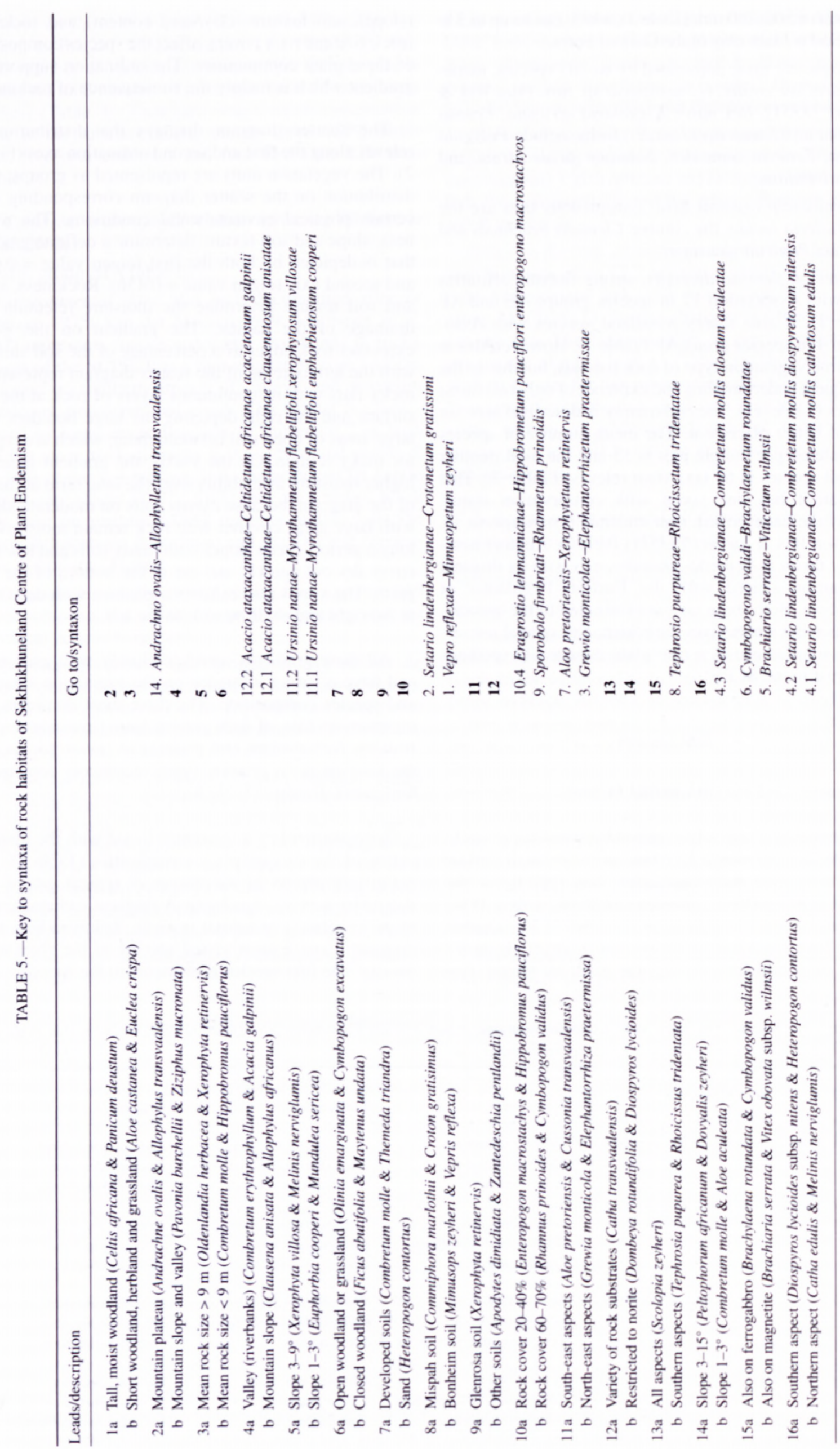


munity only, and the second is dominant, but also occurs in other communities. Where one species is given, no species was restricted to the group only.

\section{Diversity and conservation}

Much of the vegetation distribution of the SCPE is attributed to the vegetation dynamics and historic evolution of the floristics of the region, which is influenced by three factors, climate, topography and soils (Siebert 1998). It has been shown that the vegetation of rocky outcrops is specifically adapted to the chemical environment (Morrey et al. 1989; Bredenkamp \& Deutschlander 1995; Tyler 1996). When considering the large number of associations described in this paper, it is speculated that the soil chemistry of the rock habitats in the SCPE is partly responsible for the unique communities and plant diversity that occur there (Siebert 2001).

Rock habitats are characterized by high spatial heterogeneity due to the range of differing aspects and slopes (topography), all of which result in differing soil, light and hydrological conditions. Variation in aspect and soil drainage has proven to be an important predictor of plant diversity in the SCPE (Siebert 2001). This is attributed to landscapes with spatially heterogeneous abiotic conditions, which provide a diversity of potential niches for plants. Plant species richness and diversity is significantly higher in sites with high geomorphological heterogeneity (Burnett et al. 1998). However, rock habitats are usually isolated, which means that should they be disturbed, the species richness will be influenced negatively due to the long distances between similar plant communities (Bruun 2000).

Vegetation units or rock habitats in the SCPE require special protection against disturbances and should be considered for conservation purposes in the light of the rapidly developing mining industry of the region. Already, some plant communities of rock habitats in the SCPE (especially the rocky refugia) are not as diverse as they were in the past, due to extensive harvesting of firewood and building material (Crookes et al. 2000). These Afromontane forests of rocky refugia are of continental conservation importance (White 1981). In addition, certain SCPE plant endemics of rock habitats are restricted to specific communities, and once removed, will probably not return. If it is considered that 'disclimax' in dry woodlands ( $<1000 \mathrm{~mm} /$ annum) created through past land use activities, will not develop into stands similar to the previous state (Roth 1999), and given the present state of fragmentation and continued disturbance taking place within SCPE ecosystems, the rock habitats of the SCPE require immediate attention. All the plant communities of rock habitats presented in this paper are of conservation value, as they provide important islands to sustain biodiversity.

\section{CONCLUSIONS}

The classification obtained by TWINSPAN and refined by Braun-Blanquet procedures resulted in 17 vegetation units (plant communities) that can be related to environmental factors. These vegetation units should be considered as ecologically interpretable plant communi- ties for the area concerned. The classification of these vegetation units as associations is supported by the results of the ordination that pointed towards meaningful relationships between the vegetation and habitat gradients.

It is hoped that the classification and description of the different vegetation units will make a significant contribution towards the understanding of the plant communities of rock habitats of the SCPE and in southern Africa as a whole. The information supplied in this paper can be meaningfully applied in the management and conservation of the respective areas. Proper and sound future assessment of the region's vegetation should include aspects such as species richness, rarity and habitat preference. Such studies will further contribute and benefit decisions on land use management and conservation, and might hold solutions for the rehabilitation of areas disturbed by mining activities in this region.

\section{ACKNOWLEDGEMENTS}

Our thanks to Ms Martie Dednam, H.G.W.J. Schweickerdt Herbarium (PRU), University of Pretoria, for the processing of plant specimens, and the Curator and staff of the National Herbarium (PRE) in Pretoria, for assistance with plant identification. The National Research Foundation, University of Pretoria, Edward Mellon Foundation and Department of Environmental Affairs and Tourism financially supported this project. The South African Weather Bureau provided the rainfall and temperature data.

\section{REFERENCES}

ACOCKS, J.P.H. 1988. Veld Types of South Africa, edn 3. Memoirs of the Botanical Survey of South Africa No. 57.

BEDWARD, M., PRESSEY, R.L. \& KEITH, D.A. 1992. A new approach for selecting fully representative reserve networks: addressing efficiency, reserve design and land suitability with an iterative analysis. Biological Conservation 62: 115-125.

BLOEM, C. 1988. 'n Plantsosiologiese studie van die Verlorenvaleinatuarresenvaat, Transvaal. M.Sc. thesis, University of Pretoria, Pretoria.

BREDENKAMP, G.J., BEZUIDENHOUT, H., JOUBERT, H. \& NAUDE, C. 1994. The vegetation of the Boskop Dam Nature Reserve, Potchefstroom. Koedoe 37: 19-33.

BREDENKAMP, G.J. \& DEUTSCHLANDER, M.S. 1995. New azonal syntaxa from the hills and riverbanks of the Manyeleti Game Reserve, Northern Transvaal Province, South Africa. Koedoe 38: $41-58$,

BRUUN, H.H. 2000. Deficit in community species richness as explained by area and isolation of sites. Diversity and Distributions 6: 129 135.

BUCKLE, C. 1996. Weather and climate in Africa. Addison Wesley Longman, Harlow.

BURGOYNE, P.M. 1995. Phvtosociology of the north-eastern Transvaal high mountain grasslands. M.Sc, thesis, University of Pretoria, Pretoria.

BURNETT, M.R., AUGUST, P.V., BROWN, J.H. \& KILLINGBECK. K.T. 1998. The influence of geomorphological heterogeneity on biodiversity. I. A patch-scale perspective. Conservation Biology 12: $363-370$

COETZEE, B.J. 1975. A phytosociological classification of the Rustenburg Nature Reserve. Bothalia 4: 561-580.

CROOKES, D., IRELAND, C., DE WIT, M., GEACH, B., KGAME. W. \& NETSHILUVHI, T. 2000. Benefits and costs of natural resource use in Sekhukhuneland, Northern Province: case study evidence from Managaneng and Makua. Unpublished Report No. ENV-P-I-2000-013. CSIR. Pretoria.

DEALL, G.B. 1985. A plant-ecological study of the Eastern Transvaal Escarpment in the Sabie area. M.Sc. thesis, University of Pretoria. Pretoria. 
EDWARDS, D. 1983. A broad-scale structural classification of vegetation for practical purposes. Bothalia 14: 705-712.

ERASMUS, J.F. 1985. Rainfall deciles for the Transvaal Region. Report GB/A/87/18: 147-216. Soil and Irrigation Research Institute, Pretoria

HENNEKENS, S. 1996a. TURBOVEG: software package for input, processing, and presentation of phytosociological data. User's guide. IBN-DLO, Lancaster University.

HENNEKENS, S. 1996b. MEGATAB: a visual editor for phytosociological tables. User's guide. Giesen \& Geurts, Ulft.

HILL, M.O. 1979a. TWINSPAN: a FORTRAN program for arranging multivariate data in an ordered two way table by classification of individuals and attributes. Cornell University, Ithaca, New York.

HILL, M.O. 1979b. DECORANA: a FORTRAN program for detrended correspondence analysis and reciprocal averaging. Cornell University, Ithaca, New York.

HILTON-TAYLOR, C. 1996. Red Data List of southern African plants. Strelitzia 4. National Botanical Institute, Pretoria.

JONSSON, B.G. \& MOEN, J. 1998. Patterns in species associations in plant communities: the importance of scale. Journal of Vegetation Science 9: 327-332.

KENT, L.E. (ed.). 1980. Stratigraphy of South Africa: lithostratigraphy of the Republic of South Africa, South West Africa/Namibia and the Republics of Transkei, Bophuthatswana, Venda. Government Printer, Pretoria.

LAND TYPE SURVEY STAFF. 1987. Land types of the maps 2526 Rustenburg. 2528 Pretoria. Memoirs on the Agricultural Natural Resources of South Africa No. 8. Department of Agriculture and Water Supply, Pretoria.

LAND TYPE SURVEY STAFF. 1988. Land types of the maps 2426 Thabazimbi, 2428 Nylstroom. Memoirs on the Agricultural Natural Resources of South Africa No. 10. Department of Agriculture and Water Supply, Pretoria.

LAND TYPE SURVEY STAFF. 1989. Land types of the map 2530 Barberton. Memoirs on the Agricultural Natural Resources of South Africa No. 13. Department of Agriculture and Water Supply, Pretoria.

LOW, A.B. \& REBELO, A.G. (eds). 1996. Vegetation of South Africa, Lesotho and Swaziland. Department of Environmental Affairs \& Tourism, Pretoria.

MACVICAR, C.N., BENNIE, A.T.P. \& DE VILLIERS, J.M. 1991. Soil classification: a taxonomic system for South Africa. Department of Agricultural Development, Pretoria.

MADULID, D.A. \& AGOO, E.M.G. 1995. Assessment of the vegetation of Philippine mountains on ultramafic rocks. In T. Jaffre. R.D. Reeves \& T. Becquer, The ecology of ultramafic and met. alliferous areas: 113-118. Centre de Noumea, Orstrom.

MATTHEWS, W.S. 1991. Phytosociology of the North-eastern Mountain Sourveld. M.Sc. thesis, University of Pretoria, Pretoria.

MATTHEWS, W.S., BREDENKAMP, G.J. \& VAN ROOYEN, N. 1991. The grassland associated vegetation of the Black Reef Quartzite and associated large rocky outcrops in the North-eastern Mountain Sourveld of the Transvaal Escarpment, South Africa. South African Journal of Botany 57: 143-150.

MATTHEWS, W.S., BREDENKAMP, G.J. \& VAN ROOYEN, N. 1992 The vegetation of the dry dolomitic regions of the north-eastern Mountain Sourveld of the Transvaal escarpment, South Africa. Phytocoenologia 20: 467-488.

MEIRELLES, S.T., PIVELLO, V.R. \& JOLY, C.A. 1999. The vegetation of granite outcrops in Rio de Janeiro, Brazil, and the need for its protection. Environmental Conservation 26: 10-20.

MORREY, D.R., BALKWILL, K. \& BALKWILL, M-J. 1989. Studies on serpentine flora: preliminary analyses of soils and vegetation associated with serpentine rock formations in the southeastern Transvaal. South African Journal of Botany 55: 171-177

MUCINA, L., BREDENKAMP, G.J., HOARE, D.B. \& MCDONALD, D.J. 2000. A national vegetation database for South Africa. South African Journal of Science 96: 497, 498.

MUELLER-DOMBOIS, D \& ELLENBERG, H. 1974. Aims and methods of vegetation ecology. Wiley, New York.

REDDY, R.A., BALKWILL, K. \& MCLELLAN, T. 2001. Is there a unique serpentine flora on the Witwatersrand? South African Journal of Science 97: 485-494.

RETIEF, E. \& HERMAN. P.P.J. 1997. Plants of the northern Provinces of South Africa: keys and diagnostic characters. Strelitzia 6 National Botanical Institute, Pretoria.
ROTH, L.C. 1999. Anthropogenic change in subtropical dry forest during a century of settlement in Jaiqui Picado, Santiago Province, Dominican Republic. Journal of Biogeography 26: 739-759.

SCHURMANN, L.W.. GRABE. P-J. \& STEENKAMP, C.J. 1998. Chromium. In M.G.C. Wilson \& C.R. Anhaeusser, The minera resources of South Africa: 90-105. Handbook No. 16, Council for Geoscience. CTP Book Printers, Cape Town.

SIEBERT, S.J. 1998. Ultramafic substrates and floristic patterns in Sekhukhumeland, South Africa. M.Sc. thesis, University of Pretoria

SIEBERT, S.J. 2001. Vegetation on the ultramafic soils of the Sekhukhuneland Centre of Endemism. Ph.D. thesis, University of Pretoria.

SIEBERT, S.J. \& VAN WYK, A.E. 2001. Sekhukhuneland: floristic wealth versus platinum and chromium riches. Veld \& Flora 87 $168-173$.

SIEBERT, S.J., VAN WYK, A.E. \& BREDENKAMP, G.J. 2001. Endemism in the flora of ultramafic areas of Sekhukhuneland, South Africa. South African Journal of Science 97: 529-532.

SIEBERT, S.J., VAN WYK, A.E. \& BREDENKAMP, G.J. 2002a. The physical environment and major vegetation units of the Sekhukhuneland Centre of Plant Endemism. South African Journal of Botany 68: 127-142.

SIEBERT, S.J., VAN WYK, A.E. \& BREDENKAMP, G.J. 2002b. Vegetation ecology of Sekhukhuneland, South Africa: Combretum hereroense-Grewia vernicosa Open Mountain Bushveld. South African Journal of Botany 68: 475-496.

SIEBERT, S.J., VAN WYK, A.E. \& BREDENKAMP, G.J. $2002 \mathrm{c}$ Vegetation ecology of Sekhukhuneland, South Africa: Kirkia wilmsii-Terminalia prunioides Closed Mountain Bushveld. South African Journal of Botany 68: 497-517.

SIEBERT, S.J., VAN WYK, A.E., BREDENKAMP, G.J. \& DU PLESSIS, F. 2002d. The grasslands and wetlands of the Sekhu khuneland Centre of Plant Endemism. South Africa. Bothalia 32: 211-231

SIEBERT, S.J., VICTOR, J.E., VAN WYK, A.E. \& BREDENKAMP G.J. 2002e. An assessment of threatened plants and conservation in Sekhukhuneland. PlantLife 26: 7-18

SIEBERT, S.J., MATTHEE, M. \& VAN WYK, A.E. 2003. Semi-arid savanna of the Potlake Nature Reserve and surrounding areas in Sekhukhuneland, South Africa. Koedoe 46: 29-52.

SMIT, C.M., BREDENKAMP, G.J., VAN ROOYEN, N., VAN WYK, A.E. \& COMBRINCK, J.M. 1997. Vegetation of the Witbank Nature Reserve and its importance for conservation of threatened Rocky Highveld Grassland. Koedoe 40: 85-104.

SOUTH AFRICAN WEATHER BUREAU. 1998. Unpublished long-term weather statistics. Department of Environmental Affairs and Tourism, Pretoria.

TYLER, G. 1996. Soil chemistry and plant distributions in rock habitats of southern Sweden. Nordic Journal of Botany 16: 609-635

VAN DER MEULEN, F. 1979. Plant sociology of the western Transvaal Bushveld, South Africa. Dissertationes Botanicae 49: 1-191.

VAN WYK, A.E. \& SMITH, G.F. 2001. Regions of floristic endemism in southern Africa: a review with emphasis on succulents. Umdaus Press, Pretoria.

VILJOEN, M.J. \& SCHURMANN. L.W. 1998. Platinum-group metals. In M.G.C. Wilson \& C.R. Anhaeusser, The mineral resources of South Africa: 532-568. Handbook No. 16, Council for Geoscience, Cape Town.

VISSER, D.J.L., COERTZE, FJ. \& WALRAVEN, F. 1989. Explanation of the 1:1000000 geological map, fourth edition, 1984: the geology of the Republics of South Africa. Transkei, Bophu thatswana, Venda and Ciskei and the Kingdoms of Lesotho and Swaziland. The Government Printer, Pretoria.

WEBER, H.E., MORAVEC, J. \& THEURILLAT, J-P. 2000. Inter national Code of Phytosociological Nomenclature, edn 3. Jour nal of Vegetation Science 11: 739-768.

WHITE, F. 1981. The history of the Afromontane archipelago and the scientific need for its conservation. African Journal of Ecology 19: 33-54.

WHITTAKER, R.H. 1977. Evolution of species diversity in land communities. Evolutionary Biology 10: 1-67.

WINTERBACH, R., BREDENKAMP, G.J., DEUTSCHL ANDER, M.S \& MUCINA, L. 2000. Preliminary syntaxonomic scheme of veg. etation classes for the central bushveld of South Africa. In P.S White, L. Mucina, J.S. Leps \& E. van der Maarel, Proceedings of the IAVS Symposium: 123-127. Opulus Press, Uppsala. 